This is the final peer-reviewed accepted manuscript of

Antonioli, F; Anzidei, M.; AMOROSI, ALESSANDRO; Lo Presti, V.; Mastronuzzi, G.; Deiana, G.; De Falco, G.; Fontana, A.; Fontolan, G.; Lisco, S.; Marsico, A.; Moretti, M.; Orrù, P. E.; Sannino, G. M.; Serpelloni, E.; Vecchio, A.: Sea-level rise and potential drowning of the Italian coastal plains: Flooding risk scenarios for 2100. QUATERNARY SCIENCE REVIEWS, 158. 0277-3791

DOI: 10.1016/j.quascirev.2016.12.021

The final published version is available online at:

http://dx.doi.org/10.1016/j.quascirev.2016.12.021

Rights / License:

The terms and conditions for the reuse of this version of the manuscript are specified in the publishing policy. For all terms of use and more information see the publisher's website.

This item was downloaded from IRIS Università di Bologna (https://cris.unibo.it/)

When citing, please refer to the published version. 


\title{
Sea-level rise and potential drowning of the Italian coastal plains: Flooding risk scenarios for 2100
}

\author{
F. Antonioli ${ }^{\text {a, }}{ }^{*}$, M. Anzidei ${ }^{\text {b }}$, A. Amorosi ${ }^{\text {c }}$, V. Lo Presti ${ }^{\text {a }}$, G. Mastronuzzi ${ }^{\text {d }}$, G. Deiana ${ }^{\text {e }}$, \\ G.De Falco ${ }^{f}$, A. Fontana ${ }^{g}$, G. Fontolan ${ }^{\text {h }}$, S. Lisco ${ }^{\text {d }}$, A. Marsico ${ }^{d}$, M. Moretti ${ }^{d}$, P.E. Orrù e \\ G.M. Sannino a , E. Serpelloni ${ }^{\text {b }}$, A. Vecchio ${ }^{\text {i }}$ \\ ${ }^{a}$ ENEA, SSPT, Roma, Italy \\ ${ }^{\mathrm{b}}$ Istituto Nazionale di Geofisica e Vulcanologia, Roma, Italy

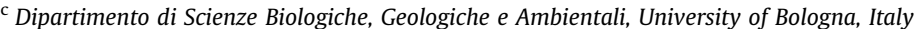 \\ d Dipartimento di Scienze della Terra e Geoambientali, University "Aldo Moro", Bari, CONISMA, Italy \\ e Dipartimento di Scienze Chimiche e Geologiche, University of Cagliari, CONISMA, Italy \\ IAMC-CNR Oristano, Italy \\ ${ }^{g}$ Dipartimento di Geoscienze, University of Padova, Conisma, Italy \\ ${ }^{\mathrm{h}}$ Dipartimento di Matematica e Geoscienze, University of Trieste, CONISMA, Italy \\ ${ }^{\mathrm{i}}$ Lesia Observatoire de Paris, Section de Meudon 5, France
}

\section{A R T I C L E I N F O}

Keywords:

Relative sea-level rise

Marine flooding

Climate change

2100 Coastline scenario
A B S T R A C T

We depict the relative sea level rise scenarios for the year 2100 from four areas of the Italian peninsula. Our estimates are based on the Rahmstorf (2007) and IPCC AR5 reports 2013 for the RCP 8.5 scenarios (www.ipcc.ch) of climate change, adjusted for the rates of vertical land movements (isostasy and tectonics). These latter are inferred from the elevation of MIS 5.5 deposits and from late Holocene sea level indicators, matched against sea level predictions for the same periods using the glacio hydro isostatic model of Lambeck et al. (2011). We focus on a variety of tectonic settings: the subsiding North Adri atic coast (including the Venice lagoon), two tectonically stable Sardinia coastal plains (Oristano and Cagliari), and the slightly uplifting Taranto coastal plain, in Apulia. Maps of flooding scenarios are shown on high resolution Digital Terrain Models mostly based on Lidar data. The expected relative sea level rise by 2100 will change dramatically the present day morphology, potentially flooding up to about $5500 \mathrm{~km}^{2}$ of coastal plains at elevations close to present day sea level.

The subsequent loss of land will impact the environment and local infrastructures, suggesting land planners and decision makers to take into account these scenarios for a cognizant coastal management. Our method developed for the Italian coast can be applied worldwide in other coastal areas expected to be affected by marine ingression due to global climate change.

\section{Introduction}

Instrumental and observational data show that in the past two centuries global sea level has risen at faster rates than in the last two or three millennia (Veermer and Rahmstorf, 2009; Church et al., 2010; Church and White, 2011; Kemp et al., 2011), with values up to $3.2 \mathrm{~mm} / \mathrm{yr}$ in the last decades (Meyssignac and Cazenave, 2012; Mitchum et al., 2010; Jevrejeva et al., 2008, 2014; Woppelmann and Marcos, 2012).

\footnotetext{
* Corresponding author.

E-mail address: fabrizio.antonioli@enea.it (F. Antonioli).
}

The recent report on global climate change (Church et al., 2013) warned countries on the risk induced by sea level rise (Fig. 1). This warning must be seriously considered for the assessment of coastal vulnerability and flooding hazard in response to the fast retreat of the coastline (Schaeffer et al., 2012; Rahmstorf et al., 2011). In addition, natural or anthropogenic coastal subsidence at rates of several $\mathrm{mm} / \mathrm{yr}$ may represent a critical factor for accelerating local coastal changes, especially when in combination with sea level rise (Carbognin et al., 2004; Syvitski et al., 2009; Karim and Mimura, 2011; Anzidei et al., 2016).

In Europe, about 86 million people (19\% of the entire population) are estimated to live within $10 \mathrm{~km}$ from the coastline (Carreau 


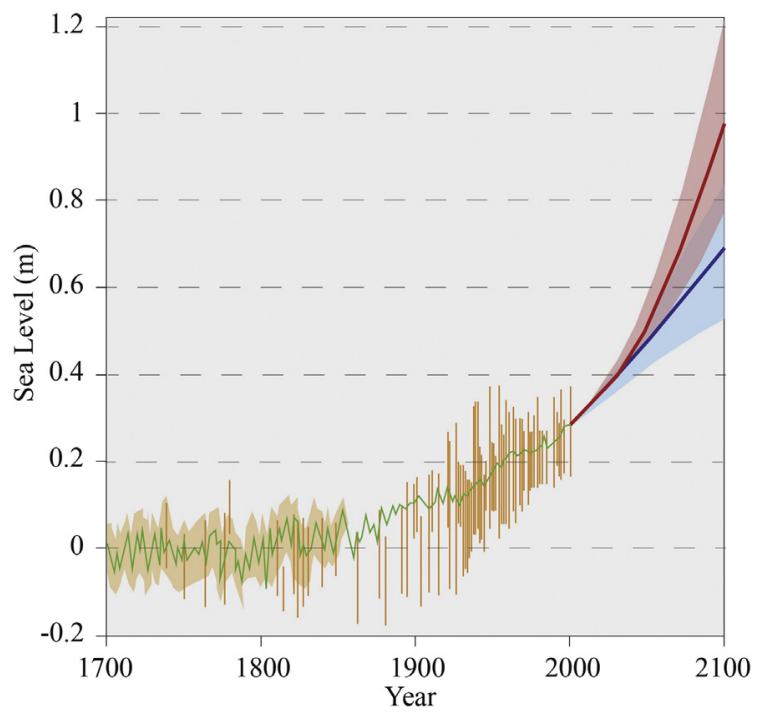

Fig. 1. Projection of global sea-level rise from 1700 to 2100, based on IPCC AR5 report on temperature projections for different emission scenarios (www.ipcc.ch, 2013). Past and future sea levels: for the past periods, proxy data are shown in light brown, for the future, the IPCC projections are reported for two different emissions: very high (red, scenario RCP8.5) and very low emissions (blue, RCP 2.6 scenario). (For interpretation of the references to colour in this figure legend, the reader is referred to the web version of this article.)

and Gallego, 2006) in contrast, most of the Mediterranean population (about 75\%) lives in coastal areas. In Italy, where coasts are stretching for more than $7500 \mathrm{~km}$, this value is up to $70 \%$ (annuario.isprambiente.it). Here, rapid urbanization started after the 60s of the 20th century, leading to the uncontrolled expansion of coastal settlements, today exposed to increasing coastal hazard (Sterr et al., 2003). In addition, the Italian coasts, which are often characterized by natural heritage sites, host important urban and industrial installations and continuously growing tourist activities (D'Alessandro et al., 2002).

Though several studies attempted to predict global sea level change at 2100 (Church et al., 2010, 2013; Rahmstorf, 2007; Galassi and Spada, 2014; Kopp et al., 2016) (Table 1) or even up to 2200 (Zecca and Chiari, 2012), in few cases only sea level rise projections were used in combination with high resolution Digital Terrain Models (DTM) and with geological and geomorphological landscape changes for long to middle term trends derived from local field data to draw detailed maps of expected coastal flooding.

DTMs have provided crucial advancements in topographic measurements, improving significantly the spatial resolution available to Earth scientists in different environments (Achilli et al., 1998; Pesci et al., 2007; Hengl and Reuter, 2009; Fabris et al., 2010; Baiocchi et al., 2007; Baltsavias et al., 2001). From the widely used $90 \mathrm{~m}$ resolution global DEM produced by the Shuttle Radar Topography Mission (Farr et al., 2007), now DTMs with considerably higher (better than $1 \mathrm{~m}$ ) resolution are available from LiDAR surveys. Therefore, the analysis of $3 \mathrm{D}$ high resolution topography is significantly enhancing coastal studies to estimate future land scape changes through time in relation to sea level rise (Anzidei et al., 2016; Antonioli et al., 2002; https://coast.noaa.gov/digitalcoast/ tools/slr.html).

Among the pioneering studies that considered the contribution of land subsidence to flooding hazard, we recall Bondesan et al. (1995), who applied $66 \mathrm{~cm}$ of sea level rise for the North Adriatic coast of Italy. While Karim and Mimura (2011) estimated the impact of sea level rise and flooding induced by cyclones storms, in western Bangladesh; in North America, Strauss et al. (2012) high lighted that half West and East coasts of the U.S. are at high or very high risk of sea level rise. Using a tidally adjusted approach, they estimated that 3.7 million of people living in 2150 coastal cities placed at about $1 \mathrm{~m}$ above sea level have some degree of exposure to sea flooding. Rosenzweig et al. (2011) realized detailed flooding maps for New York and the surrounding coastal areas, for minimum and maximum values of expected sea level rise for 2100 , at 22 and $58 \mathrm{~cm}$, respectively (Church et al., 2008). These results were used to propose an adaptation plan that included a storm surge barrier placed in the near offshore, facing the coast of New York City, although vertical land movements have not been considered in the relative sea level rise scenarios.

In the Mediterranean, many coasts are presently submerging or expected to flood in consequence of sea level rise, storm surge and tsunamis, as inferred from seismic, geodetic, geological and archaeological evidence (Anzidei et al., 2014). The most critical areas include the coasts of Turkey (Anzidei et al., 2011), the northern Adriatic (Antonioli et al., 2007; Lambeck et al., 2011), the Aeolian islands (Anzidei et al., 2016), the coast of central Italy (Aucelli et al., 2016) and eastern Morocco (Snoussi et al., 2008). For the Italian region, Lambeck et al. (2011) provided a sea level rise projection for 2100 , using an extensive database that included the isostatic and tectonic contribution to the IPCC, 2007 (https://www. ipcc.ch/pdf/assessment report/ar4/wg2/ar4_wg2_full_report.pdf) and Rahmstorf (2007) climatic models. Results have shown that, assuming a minimum of $18 \mathrm{~cm}$ and a maximum of $1400 \mathrm{~mm}$ of sea level rise projections for 2100, respectively, 33 coastal zones may become at risk of marine inundation (Fig. 2).

In this research we provide a high resolution upgrade to estimate the expected effects of sea level rise by 2100 for selected zones of the Italian coasts. Our scenarios are based on the last IPCC report (Church et al., 2013) and Rahmstorf (2007) projections, high resolution DTMs and rates of vertical land movements, including the glacio hydro isostatic model of Lambeck et al.(2011).

We focused on four coastal plains (the wide North Adriatic coastal plain, Taranto in Apulia, Cagliari and Oristano in Sardinia Fig. 2) that cover a wide spectrum of vertical tectonic phenomena, being located in stable (Sardinia), slightly uplifting (Apulia) and subsiding (North Adriatic) tectonic settings, respectively. These coastal plains are highly sensitive to sea level rise in terms of dy namic geomorphological response, landscape modifications and rapid environmental changes.

Table 1

Predicted sea level scenario for 2100, from Kopp et al. (2016) all values are computed without vertical

\begin{tabular}{|c|c|c|c|c|c|}
\hline $\begin{array}{l}\text { MIOvenाIएाts. } \\
\text { Scenario }\end{array}$ & $\begin{array}{l}\text { IPCC } 2013 \\
\min \max \\
\text { mm }\end{array}$ & $\begin{array}{l}\text { Kopp et al., } 2016 \\
\text { min max } \\
\text { mm }\end{array}$ & $\begin{array}{l}\text { Mengel et al., } 2016 \\
\text { min max } \\
\text { mm }\end{array}$ & $\begin{array}{l}\text { Horton et al., } 2014 \\
\text { min max } \\
\text { mm }\end{array}$ & $\begin{array}{l}\text { Rahmstorf } 2007 \\
\text { Scenario } \\
\mathrm{mm}\end{array}$ \\
\hline RCP 2.6 & 280600 & 240610 & 280560 & 250700 & \\
\hline RCP 4.5 & 350700 & 330850 & 370770 & n.a. & \\
\hline RCP 6.0 & 390730 & & & & \\
\hline RCP 8.5 & 530970 & 5201310 & $570 \quad 1310$ & $500 \quad 1500$ & $500 \quad 1400$ \\
\hline
\end{tabular}




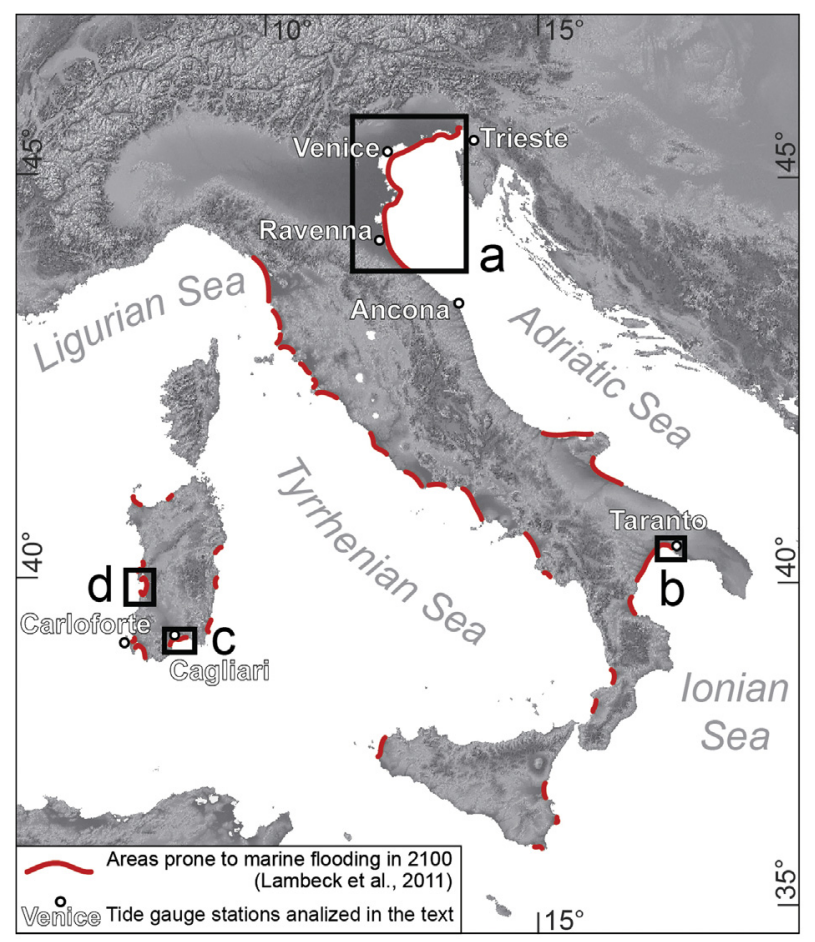

Fig. 2. Location of the investigated areas (red rectangles); in red are indicated the additional areas prone to marine flooding (Lambeck et al., 2011): a - North Adriatic; b Taranto; c Cagliari; $d$ - Oristano. Tide gauge stations discussed in this study fall in the investigated areas. (For interpretation of the references to colour in this figure legend, the reader is referred to the web version of this article.)

Here, we present high resolution maps depicting the expected shoreline position by the year 2100 and the extension of potentially flooded lands in response to relative sea level rise. Results are discussed against current trends of vertical land movements and sea level changes using instrumental data from GPS and tide gauges stations. Our maps clarify the impact of relative sea level rise in consequence of climate change and vertical tectonics, and should be considered for a conscious land planning and for adap tation strategies. Covering a large spectrum of geodynamic settings, this study may represent a general example of inundation pro cesses for several coastal systems around the world.

\section{Methods}

In order to provide the relative sea level rise projections for the preparation of flooding scenarios maps at 2100, we applied a multidisciplinary approach that includes sea level rise estimates as obtained by the IPCC (www.ipcc.ch), Rahmstorf 2007 and land topography. Our approach, as proposed in Lambeck et al., (2004a,b) "Sea level change along the Italian coast is the sum of eustatic, glaciohydro isostatic, and tectonic factors. The first is global and time dependent while the latter two also vary with location", consists to sum the different components of sea level rise in the following main steps: $a$ ) the IPCC AR5 projections (RCP 8.5 scenarios) or Rahmstorf 2007 ; b) the long term land vertical movements from geological data; c) the glacio hydro isostatic movement (also named GIA); d) by combining eustatic, isostatic and teconic data projected up to 2100 , we provided the lower and upper bounds of the expected sea levels at 2100 for the investigated regions and the expected inland extent of related marine flooding. To obtain a high resolution 3D model of the coastal area and coastline position we produced some flooding sea maps using DTM (digital terrain model) by available data of Lidar surveys we produced the maps using the method described above.

\subsection{Relative sea level rise and coastal flooding evaluation}

In this study, we used (i) the global IPCC AR5 estimates, based on the RCP 8.5 emission scenarios (www.ipcc.ch, Church et al., 2013, $380 \mathrm{ppm}$ or $700 \mathrm{ppm} \mathrm{CO} \mathrm{CO}_{2}$ in atmospheric content), and (ii) the Rahmstorf (2007) model, which provides an estimation of the eustatic sea level change up to 2100 . The IPCC AR5 indicates minimum and maximum values of global sea level rise at 530 and $970 \mathrm{~mm}$ respectively (Fig. 13.11, pag. 1186 of IPCC 2013 report) while Rahmstorf (2007) using a semi empirical relation that connects global sea level rise to global mean surface temperature suggests a maximum level of about $1.400 \mathrm{~mm}$ (Fig. 4 pag. 370 of the Rahmstorf paper).

We added to the global sea flooding scenarios the local vertical land movement that includes GIA and vertical tectonic values. Once the long term mean rates of vertical land movements (tectonic and GIA) were included in the analysis, the resulting relative sea level projections for the investigated areas were estimated as shown in Fig. 3 and Table 2 .

\subsection{Glacio hydro isostatic rates}

Relative sea level changes along coastal systems depend on the sum of climatic and geological processes attributed to eustasy, glacio hydro isostasy and tectonics (including natural ground compaction) (Lambeck and Purcell, 2005). This implies that any rigorous prediction of future land flooding should accurately take into account the contributions of vertical land movements. In order to reconstruct reliable estimates of these movements, we used the latest glacio hydro isostatic predictions (GIA) for the Italian area (geophysical model K33_j1b_WS9_6), including the most recent developments for the ice sheets from both hemispheres (Lambeck et al., 2011). This model includes the extension of major ice sheets, back to the penultimate interglacial, as well as an Alpine deglaciation model, and considers no changes in ocean volume for the past few centuries. Rheological parameters were adopted from previous studies for the same region (Lambeck et al., 2004a, b), which used a three layer model with elastic lithospheric thickness of $65 \mathrm{~km}$, upper mantle viscosity of $3 \times 10^{20} \mathrm{~Pa}$, and lower mantle viscosity of $3 \times 10^{22} \mathrm{~Pa}$. The ongoing crustal response to the past deglaciations along the Italian coast corresponds up to $0.45 \mathrm{~mm} / \mathrm{yr}$ of sea level rise in the Gulf of Taranto, $0.62 \mathrm{~mm} / \mathrm{yr}$ in Sardinia and $0.12 \mathrm{~mm} / \mathrm{yr}$ in the north Adriatic (Table 2). These values, derived from the Fig. 3, pag. 252 of Lambeck et al., 2011 and will remain about the same for the next 500 years.

\subsection{Rates of vertical land tectonic since the last $125 \mathrm{ka} \mathrm{BP}$}

To account for vertical land tectonic movements, we evaluated the long term tectonic rates along the various coasts of Italy. We used the elevation of MIS 5.5 deposits to estimate the long term tectonic rates, which in the study area (Fig. 2) range from $1.05 \mathrm{~mm} / \mathrm{yr}$ to $+1.9 \mathrm{~mm} / \mathrm{yr}$ (Ferranti et al., 2006, 2010; Antonioli et al., 2007, 2009). In particular, in the subsiding north Adriatic coastal plain, downlift rates increase from north to south: the lowest values $(0.3 \div 0.5 \mathrm{~mm} / \mathrm{yr})$ are observed between Trieste and Caorle; higher values $(0.5 \div 0.7 \mathrm{~mm} / \mathrm{yr})$ are recorded between Caorle and Chioggia and between Comacchio and Ravenna $(0.7 \div 0.9 \mathrm{~mm} / \mathrm{yr})$, while the highest $(0.7 \div 1.0 \mathrm{~mm} /$ yr) are between Chioggia and Cesenatico (Fig. 4 and Table 2).

Recent studies on the geodynamics of southern Apulia (Di Bucci et al., 2011) and the elevation of the Holocene sediments from a 

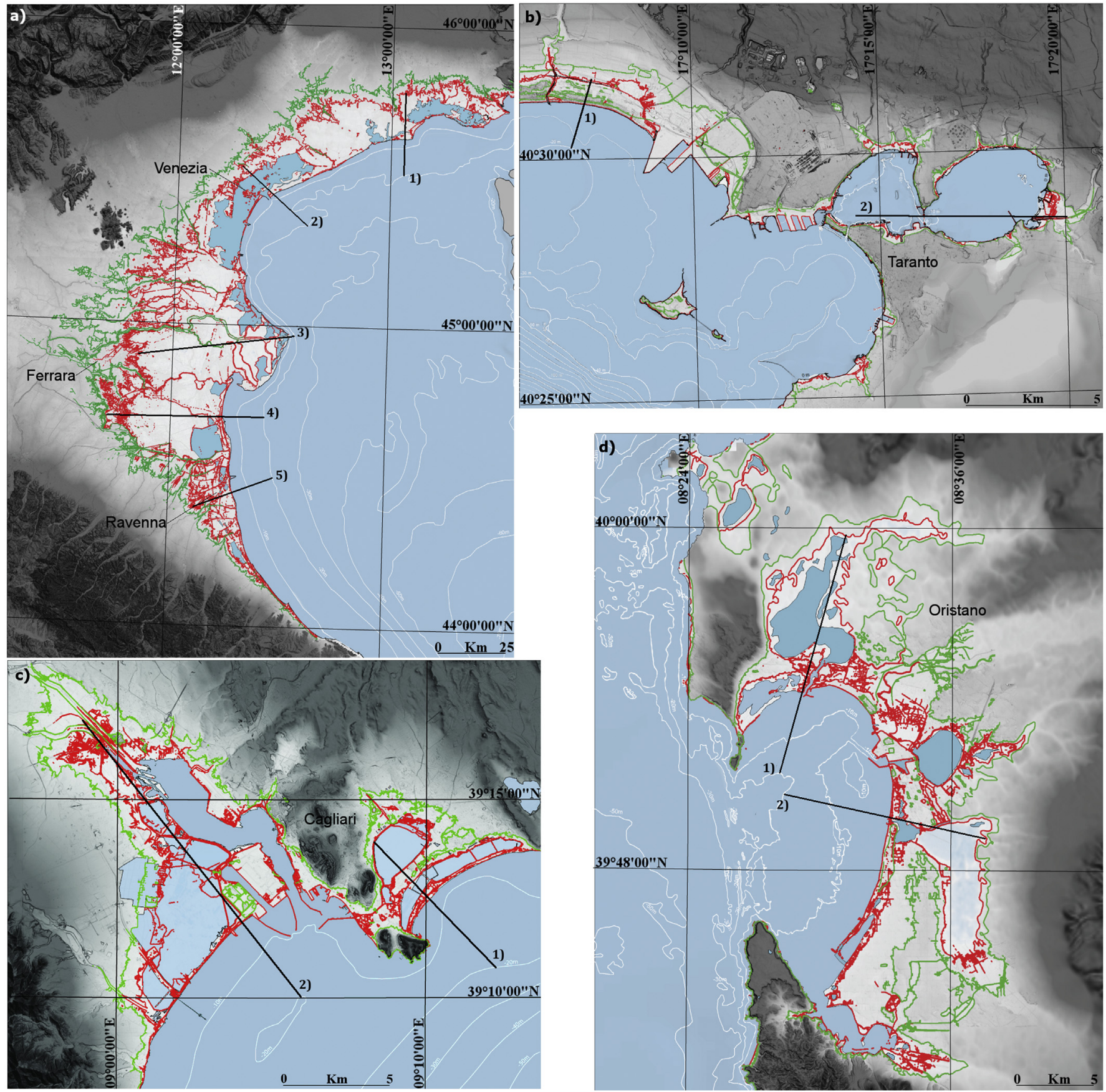

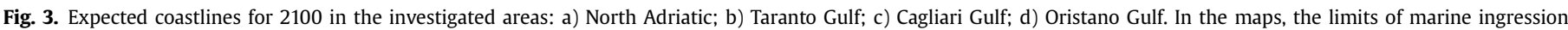
expected for 2100 for the Rahmstorf scenarios (2007, red line) and the $5 \mathrm{~m}$ contour line (in green) are shown for each area.

shallow marine core in Taranto suggest vertical tectonic stability of this region for the last $3 \mathrm{ka}$. While elevation of MIS 5.5 deposits at $23 \mathrm{~m}$ a.s.l. in the Taranto area (Amorosi et al., 2014; Negri et al., 2014; Lisco et al., 2015) and up to $40 \mathrm{~m}$ a.s.l. between Metaponto and Policoro (Mastronuzzi and Sansò, 2003 and references therein) indicate significant long term uplifting of the Ionian coast, values of less than $2 \mathrm{~m}$ are recorded in southern Salento, i.e. the southern most tip of Apulia (Mastronuzzi and Sansò, 2002; Mastronuzzi et al., 2007). Based on the available data, a mean rate of uplift at 0.14 $\mathrm{mm} / \mathrm{yr}$ was adopted for the Taranto coast (Table 2 ).

The coasts of Sardinia, including the gulfs of Oristano and Cagliari, are instead tectonically stable, as inferred from the elevation of the MIS 5.5 notch between 4 and $8 \mathrm{~m}$ a.s.l., and of last interglacial deposits (Ferranti et al., 2006; Orrù et al., 2011; 2014; De Falco et al., 2015). While in correspondence of the Holocene sedimentary infilled lagoons of Mistras (Oristano) and Santa Gilla (Cagliari) low values of subsidence $(0.2-0.5 \mathrm{~mm} / \mathrm{yr})$ are recorded, due to sediment compaction (Orrù et al., 2004). A weak uplift is observed locally in the Gulf of Orosei, in relation to past volcanic activity (Mariani et al., 2009).

\subsection{Digital Terrain Models}

In order to get a high resolution topography suitable for 
Table 2

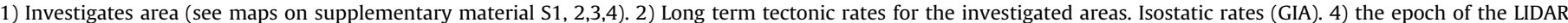

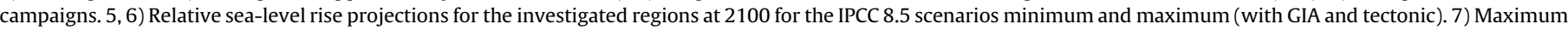
relative sea level rise projections for the investigated regions at 2100 (with GIA and tectonic) for the Rahmstorf (2007) model.

\begin{tabular}{|c|c|c|c|c|c|c|}
\hline 1) Area & 2) Tectonic Vertical Movements $\mathrm{mm} / \mathrm{yr}$ & 3) Isostatic rates $\mathrm{mm} / \mathrm{yr}$ & 4) Base Map (year) & $\begin{array}{l}\text { 5) RSLR } 2100 \\
\text { IPCC } 8.5 \mathrm{~min} \mathrm{~mm}\end{array}$ & $\begin{array}{l}\text { 6) RSLR } 2100 \\
\text { IPCC } 8.5 \text { max mm }\end{array}$ & $\begin{array}{l}\text { 7) RSLR } 2100 \\
\text { Rahmstorf max mm }\end{array}$ \\
\hline North Adriatic - 1 & -0.40 & -0.12 & 2003 & 565 & 992 & 1409 \\
\hline North Adriatic - 2 & -0.60 & -0.13 & 2003 & 584 & 1011 & 1428 \\
\hline North Adriatic - 3 & -0.95 & -0.21 & 2008 & 594 & 999 & 1395 \\
\hline North Adriatic - 4 & -0.78 & -0.21 & 2008 & 579 & 983 & 1379 \\
\hline Gulf of Taranto & +0.14 & -0.45 & 2008 & 516 & 921 & 1317 \\
\hline Gulf of Cagliari & 0.00 & -0.58 & 2007 & 547 & 956 & 1356 \\
\hline Gulf of Oristano & 0.00 & -0.62 & 2008 & 545 & 949 & 1345 \\
\hline
\end{tabular}

mapping the various sea level rise scenarios for the investigated areas, we analyzed the available topographic and bathymetric data produced by Lidar surveys, elevation points of the Regional maps at scale 1:5000 and bathymetry surveys. From these sources, the Digital Terrain Models (DTM) were extracted (Tarquini et al., 2007). Most of the LIDAR surveys have been performed in 2008 (Table 2), and data have been released by different agencies (Table 5), at about $30 \mathrm{~cm}$ of mean vertical resolution. The details about the characteristics of the DTM are described in the maps available in the supporting online material (S1, S2, S3 and S4). Grids were mapped and analyzed by Global Mapper Software ${ }^{\circledR}$ (www. globalmapper.com) to realize $3 \mathrm{D}$ high resolution maps of the investigated areas, on which the position of the modern coastline and the potential extension of the land flooded by 2100 (in response to relative sea level rise) were indicated. Bathymetric data derive from local coastal surveys and regional low resolution grids from GEBCO data (www.gebco.net) and the European Ma rine Observation and Data Network (EMODnet, http://portal. emodnet bathymetry.eu/). Bathymetric raster data have a grid size of $1 / 8$ per $1 / 8$ arc minutes $\left(0,00208333^{\circ}\right)$. Marine and terrestrial topographic data were co registered and georeferenced into the same UTM WGS84 (Zone 32 and 33) reference frame, and shoreline

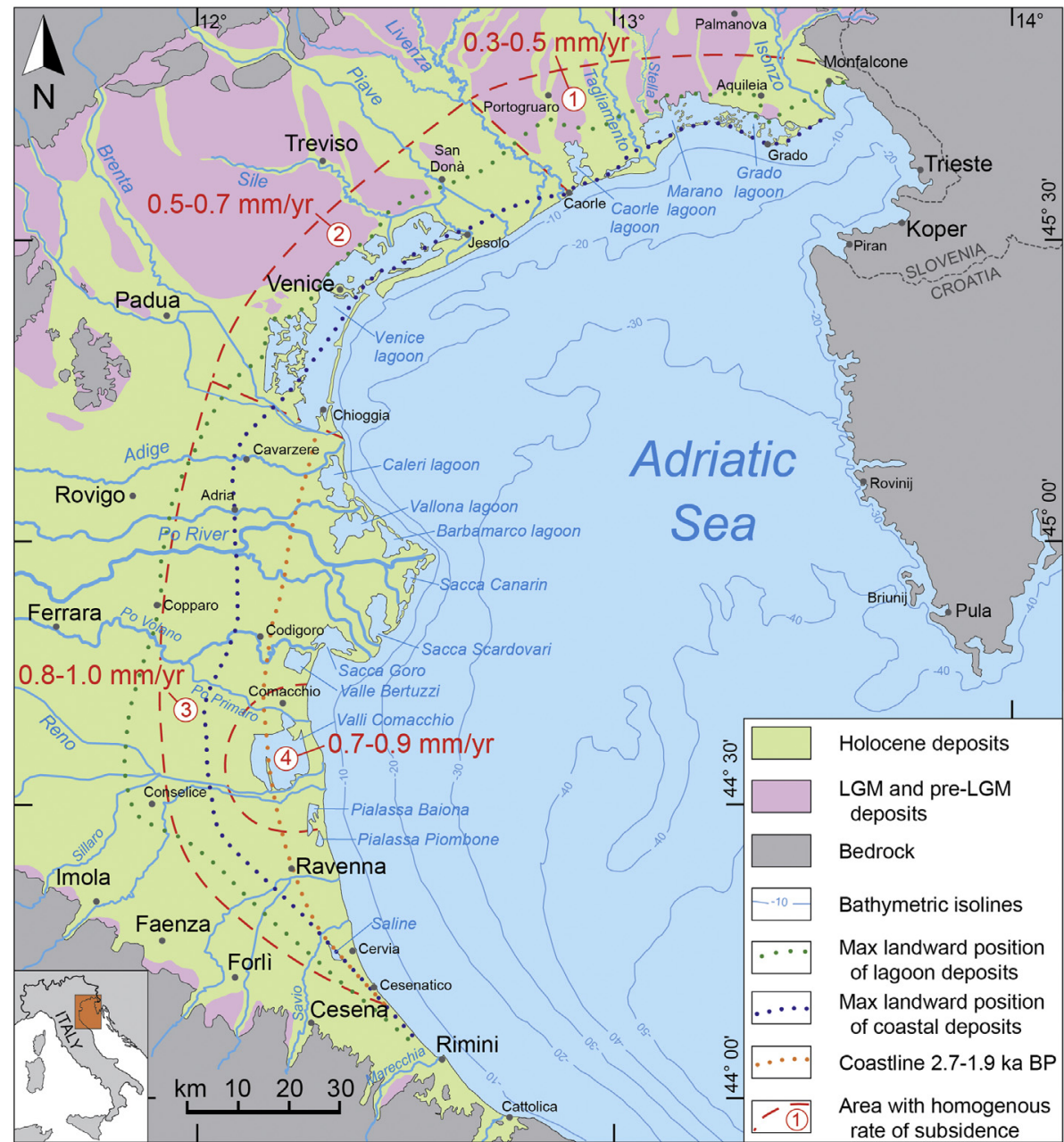

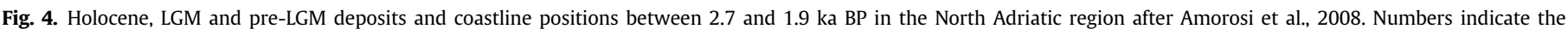
geological rates of land subsidence. 
position was determined relative to the epoch of the surveys for each area.

\section{Current rates of sea level trend and vertical land motion from GPS}

In order to check the amount of vertical movement obtained (Chapter 2.3 and 2.4) we used also the short term instrumental data. The time series of tidal data from the Revised Local Reference (RLR) of the Permanent Service for Mean Sea Level (www.psmsl. org) and of the Italian tidal network managed by ISPRA (www. mareografico.it) were analyzed to estimate the current relative sea level trends at individual stations. Historical monthly records spanning more than one hundred years are available for the Trieste (1875-2012) and Venice "Punta della Salute" (1909-2000) stations. Besides these long time series of sea level data, a set of tidal stations that fall in the study area (Ancona, Cagliari, Carloforte, Ravenna, Taranto, Trieste and Venice) is also available from the Italian network managed by ISPRA (www.mareografico.it) that collected records in the period 1999-2013. Data gaps and errors (false zeros and spikes) were identified and eliminated during the analysis to avoid the introduction of artificial signals from the records. Since Trieste shows 11 years of data gap at the beginning of the recordings, the new ISPRA station in Trieste was discarded due to malfunctioning. The spatial distribution of the investigated tidal stations is shown in Fig. 2. The sea level time series, with trends and rates as obtained from a linear fit regression of the available data, are reported in Fig. 5 and Tables 3 and 4.

In addition to local sea level trend, the short term rates of vertical land motion were constrained by continuous GPS (cGPS) data. Geodetic rates of vertical land motion were obtained from the analysis of position times series by Gamit software (Herring et al., 2010), derived from the processing of raw data collected by several cGPS networks operating in the Euro Mediterranean area. Here, we followed the approach of Serpelloni et al. (2013), which includes the removal of the spatially correlated common mode error in GPS time series and the estimate of vertical rates, while accounting for the spectral characteristics of noise in the displacement time series. All raw GPS data for the period 1992-2015 were fully reprocessed following the most updated IGS recommendations for the REPRO2 global reprocessing campaign (http://acc.igs.org/reprocess2). This resulted in a set of regional solutions that were homogenously processed with the most updated standards and models. GPS velocities were realized in an absolute geocentric reference frame, specifically the IGb08 reali zation of the global ITRF08 (Altamimi et al., 2011). The solutions shown in Fig. 6 represent the absolute (i.e. in the IGb08 reference frame) velocities of cGPS sites located within $10 \mathrm{~km}$ from the coastlines that collected data for more than 2.5 years. These ve locities are part of a broader geodetic solution that includes more than 2000 cGPS stations in the Euro Mediterranean area. Red and blue colors indicate positive (uplifting) and negative (subsiding) vertical motion trends. The color scale is saturated to $\pm 4 \mathrm{~mm} / \mathrm{yr}$ (Fig. 6).

The pattern of vertical GPS rates in the Northern Adriatic region is a diffuse subsidence with rates close to $\sim 5 \mathrm{~mm} / \mathrm{yr}$ in the Po Delta and in the Veneto Romagna Plain. Subsidence decreases north wards, in the Friuli Plain and is close to zero in the Gulf of Trieste. The Venice Lagoon (see inset of Fig. 5), with the exception of the station VENE (whose time series is of poor quality and affected by several offsets), is characterized by subsidence rates up to $2 \mathrm{~mm} / \mathrm{yr}$ in the city of Venice, and up to $9.2 \mathrm{~mm} / \mathrm{yr}$ at TREP station (Fig. 6a), The different numerical values between the long term vertical tectonic data (Table 2) and the GPS (Fig. 6) were explained in Antonioli et al., 2009: all the cores carried out in the vicinity of the coast, older than 6 ka cal BP years (dated using biological markers well connected with sea) show similar values with the long term (MIS 5.5). All younger cores show higher values, refletting the soil compaction and loss of water (as GPS).

In Sardinia, low rates of subsidence are recorded in the eastern sector of the island (Fig. 6b). Owing to the lack of GPS stations along the Oristano gulf, the current vertical land movements are still unknown, preventing any tectonically corrected projection of relative sea level rise. The cGPS sites located along the gulf of Cagliari display subsiding rates of $\sim 0.5 \mathrm{~mm} / \mathrm{yr}$.

In Apulia, the GPS stations located close to the Gulf of Taranto display velocities close to zero, with the exception of TRE2 station, which is uplifting at $0.9 \pm 03 \mathrm{~mm} / \mathrm{yr}$ (Fig. 6c).

\section{Predicted sea-level rise and possible drowning scenarios}

Here we stress that in this research we have used global sea level rise projections provided by IPCC $(530 \mathrm{~mm}$ minimum, $970 \mathrm{~mm}$ maximum for RCP 8.5) and Rahmstorf, 2007 (500 mm minimum, $1400 \mathrm{~mm}$ maximum, Table 1 ).

To our knowledge, the most comprehensive regional projection available for the Mediterranean Sea for 2050 has been carried out only by Galassi and Spada (2014). Their analysis included terrestrial ice melt, GIA and the steric sea-level components. The first component was obtained from global scenarios for the future mass balance of the Greenland and Antarctica ice sheets, glaciers and ice caps. The second component was based on modeling, using different assumptions about the Earth's rheology and the chronology of deglaciation since the Last Glacial Maximum. The steric level component at regional scale was derived from published simulations based on Mediterranean regional atmosphere-ocean coupled models (Carillo et al., 2013).

In order to compare our results with those obtained by Galassi and Spada (2014), we have recomputed the sea level projection for 2050 using IPCC scenario RCP 6.0. (www.ipcc.ch). Doing so our projection at 2050 for the relative sea level is $337 \mathrm{~mm}, 296 \mathrm{~mm}$, and $320 \mathrm{~mm}$ for the Tyrrhenian, Adriatic and Ionian basins respectively (Table 3 column2).

Such estimations are higher than those obtained by Galassi and Spada (2014) see also Table 7 (column 2). However, as underlined by the authors, their estimation could be underestimated because they neglect the contribution of the salinity increase to the mass component (see also the methodological issue raised by Jordà and Gomis, 2013). As suggested by Jordà and Gomis (2013) a first or der approximation for both the Mediterranean steric sea level component and the mass component is given by the thermo metric component. Thus, substituting to the oceanic response value considered by Galassi and Spada the thermometric value computed by Carillo et al. (2013), an average increase of about $300 \mathrm{~mm}$ is obtained $(276,268,335 \mathrm{~mm}$ Table 7 column 4 . Such values appear now more similar to those obtained by our estimations (Table 7 column 2), with a maximum difference limited to $59 \mathrm{~mm}$, that however, will be further reduced when both the steric and mass component will be considered. In fact, as shown by Jordà and Gomis (2013), the difference between the thermometric effect and the steric and mass components for 2050 in the Mediterranean basin is about $50 \mathrm{~mm}$ for IPCC A2 scenario. Speculating on the difference between A2 and RCP 6.0 scenarios we expect that a substantial fraction of this $50 \mathrm{~mm}$ has to be added to the values in Table 7 (column 4). Doing so the estimation provided by Galassi and Spada turn out to be even more similar to our estimation. 


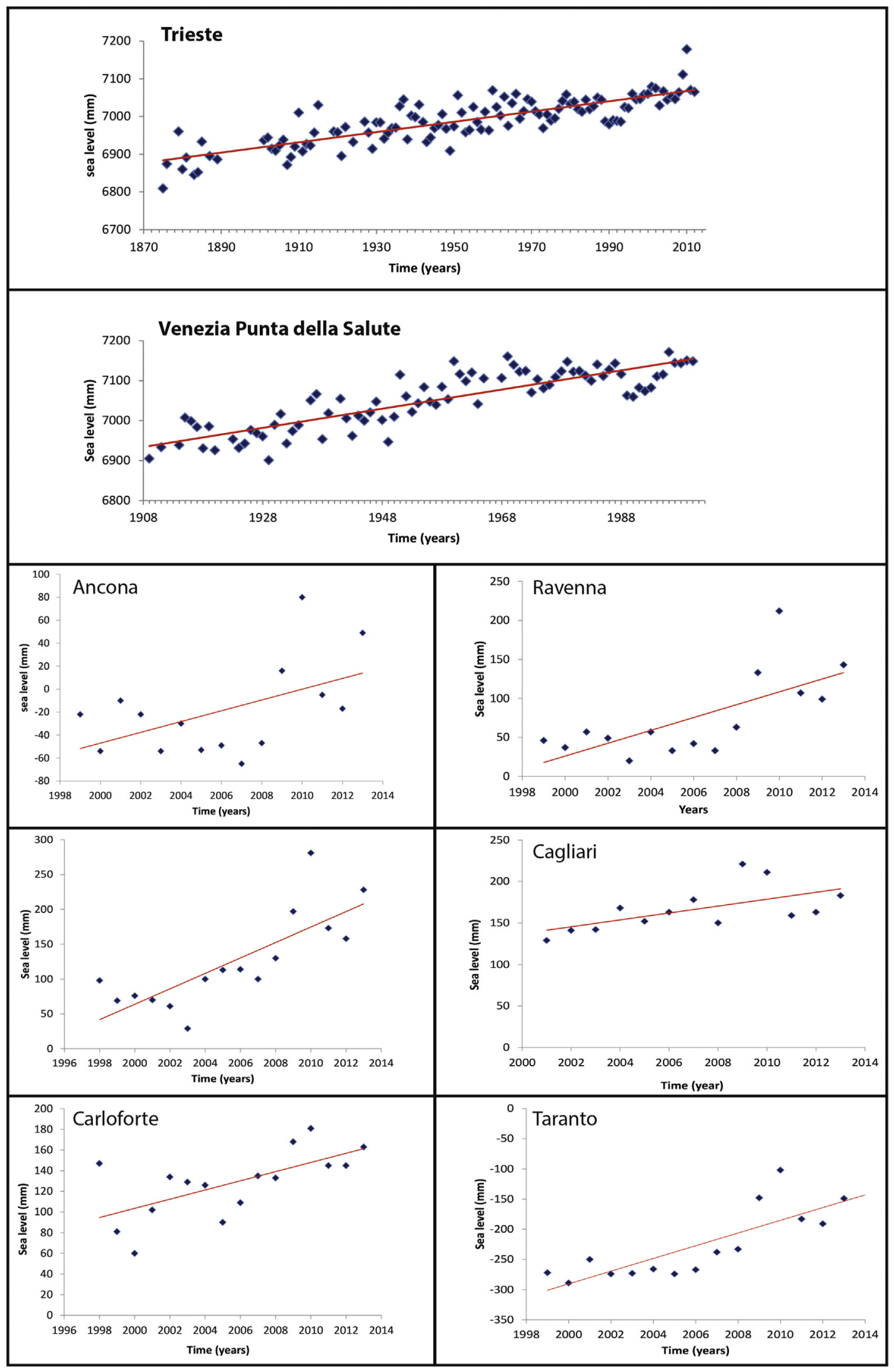

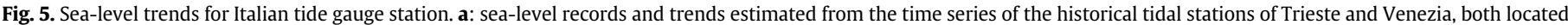

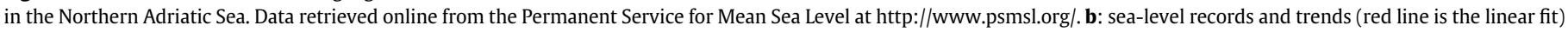

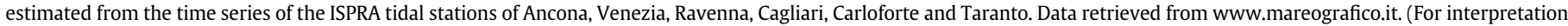
of the references to colour in this figure legend, the reader is referred to the web version of this article.) 
Table 3

Sea level rates for the 20002013 time span for the ISPRA Tidal Network. Due to the short duration of the time series, values are not representative of the long-term trends due to sea level variability.

\begin{tabular}{ll}
\hline \multicolumn{2}{l}{ Sea level trends for ISPRA stations } \\
\hline Region and tidal station & Rate $(\mathrm{mm} / \mathrm{yr})$ \\
\hline Adriatic coast & \\
Ancona & $+3.9 \pm 0.2$ \\
Venice & $+10.7 \pm 0.3$ \\
Ravenna & $+8.3 \pm 0.3$ \\
Gulf of Taranto & \\
Taranto & $+9.4 \pm 0.1$ \\
Sardinia & \\
Cagliari & $+6.8 \pm 0.1$ \\
Carloforte & $+5.6 \pm 0.1$ \\
\hline
\end{tabular}

Table 4

Sea-level rates (linear fit) for historical stations for the 18752011 time span.

\begin{tabular}{lll}
\hline Sea level trends for historical stations & N Adriatic sea & \\
\hline Tide gauge station & Time span & Rate $\mathrm{mm} / \mathrm{yr}$ \\
\hline Venezia Punta della Salute & 19092000 & $+2.44 \pm 0.1$ \\
Trieste & $1875 \quad 2011$ & $+1.32 \pm 0.1$ \\
\hline
\end{tabular}

Based on the IPCC AR5 8.5 scenario, Table 2 reports the lowest and highest expected sea level positions by 2100 for the investigated areas. These values (Table 1 ) was added with isostatic values and long term vertical tectonic rates. A maximum relative sea levels for 2100 are expected at about $1011 \mathrm{~mm}$ a.s.l. for the North Adriatic, at $959 \mathrm{~mm}$ for the gulf of Cagliari, 949 for Oristano and, and at $921 \mathrm{~mm}$ for the Gulf of Taranto (Table 2 column 6). Whereas for the same areas, according to the most severe scenario (Rahmstorf, 2007) sea level is expected to rise in the range of 1317-1428 $\mathrm{mm}$ (Table 2 column 7).

For each area, three potential landward limits of marine ingression expected by 2100 are depicted for: (i) the minimum IPCC AR5 8.5 scenario (white line), (ii) the maximum IPCC AR5 8.5 scenario (blue line), and (iii) the Rahmstorf (2007) scenario (red line). Coastline position at the time of LIDAR surveys (Table 2 ) and the $5 \mathrm{~m}$ contour line (in brown) (see supplementary material S1,S2,S3,S4) are also shown on map, highlighting inland areas currently below sea level.

The distinct coastal flooding scenarios for the different areas wereobtained converting the lines of marine ingression predicted for 2100 into polygons that were drawn on the DTMs, relative to the present day coastline. The predicted extension of flooded lands for each scenario are detailed in Table 6. In order to gather information about both submarine and ground elevations and slopes, cross sections were drawn along representative coastal zones, between the $20 \mathrm{~m}$ depth contour and across the predicted lines of Rahmstorf (2007) marine ingression (Supplementary material S 5, 6,7,8). Along each cross section, two trend lines were obtained: one for the marine environment, and the other one for the conti nental environment, which enabled calculation of maximum and mean ground slope gradients for both areas.

The role and effects of episodic events on the marine flooding are out of the scope of our analysis. Since there is no evidence of future significant changes in wave regime and extreme sea levels (Lionello et al., 2008, 2012; Benetazzo et al., 2012; Weisse et al., 2014), and considering that most of the present coastline is affecting erosion, is sediment starved and mostly modified by human defenses, the projection of the future coastline as mean flooding limit has the same significance of the present coastline, with its natural or artificial defenses, and possible overtopping due to the episodic extremes. Obviously, since flooded areas have been estimated with respect to a local mean sea level, during high tides or extreme waves from storms, the extent of flooding will temporarily affect further areas, exceeding those shown in the maps.

Among the studied areas (see also the detailed maps in Supplementary material S1, 2, 3, 4), the northern Adriatic region, being characterized by almost flat topography and high rates of land subsidence appears to be the most prone to marine flooding (Fig. 7, Fig. S1). Moreover, coastal submergence in this region is enhanced by the combined effect of river flooding and storms, high surge levels and high water spring tidal levels (Perini et al., 2016). A large portion of the foreseen flooded area today is below the mean sea level and its drainage is guaranteed by a complex system of hundreds of water pumping stations, extensively distributed all along the coastal and peri lagoon areas, as well in the neighbouring hydraulic network. Closed by lagoons and river dikes, these wide topographic depressions in the coastal system are drained through pumping stations, which are capable to move more than two million of litres of water per second. Due to the presence of impermeable terrains, which avoid marine ingression into the de pressions, the security of the coastal region will depend mostly on dike efficiency and reinforcement, while the number and efficiency of water pump stations need to be maintained. Dike elevation must necessarily be increased according to the worst relative sea level

Table 5

Features of LIDAR and bathymetric data used in this study.

\begin{tabular}{|c|c|c|c|c|}
\hline Area & Agency & Data & Resolution & Bathymetry \\
\hline $\begin{array}{l}\text { North Adriatic } \\
\text { (Friuli Venezia } \\
\quad \text { Giulia) } \\
\text { (Veneto) }\end{array}$ & $\begin{array}{l}\text { Regions of Friuli Venezia Giulia and } \\
\text { Veneto, INGV }\end{array}$ & TINITALY/01 grid of $10 \times 10$ & $10 \times 10 \mathrm{~m}$ & EMODNnet, offshore \\
\hline $\begin{array}{l}\text { North Adriatic } \\
\text { (Emilia }\end{array}$ & Italian Ministry of the Environment & $\begin{array}{l}\text { Extraordinary Plan of Environmental } \\
\text { Remote Sensing }\end{array}$ & $\begin{array}{l}1 \times 1 \mathrm{~m} \text { land } \\
2 \times 2 \mathrm{~m} \text { coast }\end{array}$ & EMODNnet, offshore \\
\hline Romagna) & Emilia Romagna Region & Regional DTM & $\begin{array}{l}5 \times 5 \mathrm{~m} \text { where no LIDAR are } \\
\text { available }\end{array}$ & \\
\hline $\begin{array}{l}\text { Gulf of Taranto } \\
\text { (Apulia) }\end{array}$ & Italian Ministry of the Environment & $\begin{array}{l}\text { Extraordinary Plan of Environmental } \\
\text { Remote Sensing }\end{array}$ & $\begin{array}{l}1 \times 1 \mathrm{~m} \text { land } \\
2 \times 2 \mathrm{~m} \text { coast }\end{array}$ & $\begin{array}{l}\text { EMODNnet, offshore } \\
\text { Mar Piccolo from Lisco et al., } 2015 \\
\text { Mar Grande from 1:20,000 Sailing } \\
\text { map (F. 148) }\end{array}$ \\
\hline $\begin{array}{l}\text { Gulf of Cagliari } \\
\text { (Sardinia) }\end{array}$ & $\begin{array}{l}\text { Autonomous Region of Sardinia } \\
\text { Italian Ministry of the Environment }\end{array}$ & $\begin{array}{l}\text { Lidar Survey } \\
\text { Extraordinary Plan of Environmental } \\
\text { Remote Sensing }\end{array}$ & $\begin{array}{l}1 \times 1 \mathrm{~m} \text { coast } \\
2 \times 2 \mathrm{~m} \text { land }\end{array}$ & EMODNnet, offshore \\
\hline $\begin{array}{l}\text { Gulf of Oristano } \\
\text { (Sardinia) }\end{array}$ & $\begin{array}{l}\text { Autonomous Region of Sardinia } \\
\text { SRTM }\end{array}$ & $\begin{array}{l}\text { Lidar survey } \\
\text { DTM }\end{array}$ & $\begin{array}{l}1 \times 1 \mathrm{~m} \text { coast } \\
30 \mathrm{~m} \text { land }\end{array}$ & $\begin{array}{l}1 \times 1 \mathrm{~m} \text { IAMC-CNR, shallow water } \\
\text { EMODNnet, offshore }\end{array}$ \\
\hline
\end{tabular}



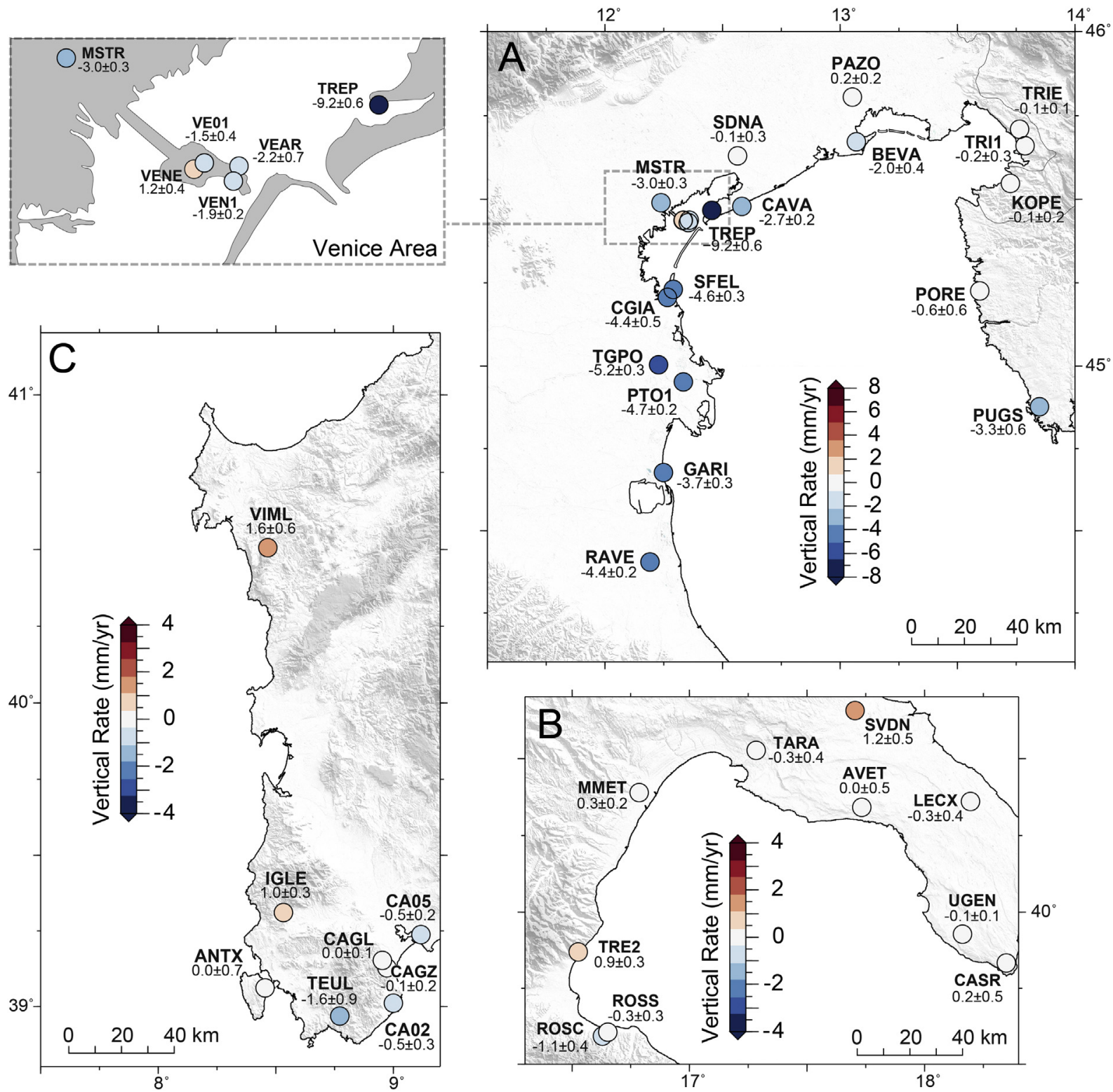

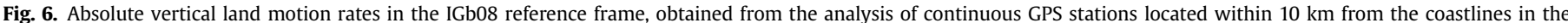

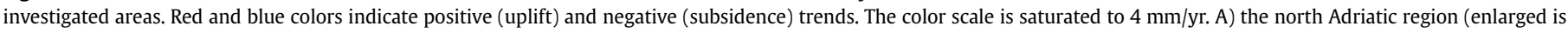

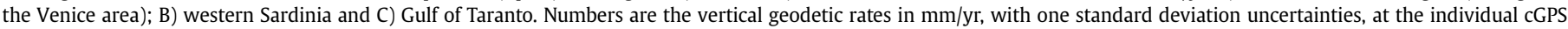
stations. (For interpretation of the references to colour in this figure legend, the reader is referred to the web version of this article.)

rise (RSLR) scenario, since low lying areas (below zero $\mathrm{m}$ of elevation) will increase by $70 \%$.

If any coastal enforcement action will be carried out in the near future the towns of Aquileia Adria, Ravenna and Rovigo are at risk of flooding in the next years as well as the town of Ferrara, while the shoreline will be located less than $10 \mathrm{~km}$ from Ferrara.

In the Gulf of Taranto (Fig. 8), the stress jointly induced by low riversediment supply and sea level rise implies significant

Table 6

Extension of flooded area $\left(\mathrm{km}^{2}\right)$, maximum distance from coastline (distance), mean ground slope of flooded zone ( $\alpha$ ) and maximum and mean ground slope along profiles reported in Fig. 3, for the IPCC 8.5 and 4.5 scenarios and Rahmstorf (2007) model.

\begin{tabular}{|c|c|c|c|c|c|c|c|c|c|c|c|c|c|}
\hline \multirow[t]{3}{*}{ Area } & \multicolumn{3}{|c|}{ IPCC 2013 AR5-8.5 min } & \multicolumn{3}{|c|}{ IPCC 2013 AR5-8.5 max } & \multicolumn{7}{|c|}{ Rahmstorf 2007 max scenario } \\
\hline & \multirow[t]{2}{*}{$\mathrm{km}^{2}$} & \multirow[t]{2}{*}{$\alpha\left({ }^{\circ}\right)$} & \multirow[t]{2}{*}{$\overline{\text { distance }(\mathrm{m})}$} & \multirow[t]{2}{*}{$\mathrm{km}^{2}$} & \multirow[t]{2}{*}{$\alpha\left({ }^{\circ}\right)$} & \multirow[t]{2}{*}{$\overline{\text { distance }(\mathrm{m})}$} & \multirow[t]{2}{*}{$\mathrm{km}^{2}$} & \multirow[t]{2}{*}{ distance $(\mathrm{m})$} & \multirow[t]{2}{*}{$\alpha\left({ }^{\circ}\right)$} & \multicolumn{2}{|c|}{ slope max } & \multicolumn{2}{|c|}{ slope mean } \\
\hline & & & & & & & & & & marine & terrestrial & marine & terrestrial \\
\hline North Adriatic & 4616.7 & 0.51 & $59,132.0$ & 4957.6 & 0.50 & $60,733.3$ & 5451.7 & $61,280.4$ & 0.49 & 0.79 & 0.01 & 0.24 & 0.00 \\
\hline Gulf of Taranto & 1.2 & 2.3 & 903.6 & 2.3 & 2.78 & 1339.2 & 4.2 & 1730.6 & 2.91 & 0.01 & -0.01 & 0.007 & 0.00 \\
\hline Gulf of Cagliari & 44.9 & 1.7 & 9137.5 & 54.0 & 1.76 & $11,776.5$ & 61.2 & $12,358.2$ & 1.83 & 0.03 & -0.001 & 0.02 & -0.00 \\
\hline Gulf of Oristano & 86.6 & 0.22 & 9787.3 & 104.2 & 0.23 & $10,290.4$ & 124.5 & $10,374.5$ & 0.25 & 0.30 & -0.03 & 0.26 & -0.02 \\
\hline
\end{tabular}


Table 7

Relative sea level rise using IPCC 2013, AR5 RCP 6 without vertical tectonic component. The isostatic values (GIA) used by Galassi and Spada (2014) are the same used in this paper.

\begin{tabular}{|c|c|c|c|c|}
\hline $\begin{array}{l}\text { 1) } 2100 \text { IPCC } \\
6.0 \mathrm{~mm} \text { with } \\
\text { GIA }\end{array}$ & $\begin{array}{l}\text { 2) } 2050 \text { IPCC } \\
6.0 \mathrm{~mm} \text { with } \\
\text { GIA }\end{array}$ & $\begin{array}{l}\text { 3) Galassi } 2014 \\
\text { IPCC } 6.0 \mathrm{~mm} \\
\text { with GIA }\end{array}$ & $\begin{array}{l}\text { 4) Galassi } 2014 \\
\text { IPCC } 6.0 \mathrm{~mm} \\
\text { with GIA and increase } 30 \mathrm{~cm}\end{array}$ & 5) Area \\
\hline 744 & 337 & 246 & 276 & Tirrhenian \\
\hline 631 & 296 & 238 & 268 & Adriatic \\
\hline 700 & 320 & 305 & 335 & Ionian \\
\hline
\end{tabular}

exposure to the risk of marine flooding, especially in the Taranto area and in the semi enclosed basin of "Mar Grande" and "Mar Piccolo". In the coastal plain west to Taranto, if high dune belts will not be destroyed by the high rates of coastal erosion, they will play a major role against flooding, which will be restricted to river mouths, as a function of future river efficiency.

In Sardinia, the maximum sea level rise estimated for Oristano by 2100 is at $1.345 \mathrm{~m}$ (Table 2 column 7). This value, in conjunction with coastal human settlements, the scarcity of river sediment discharged to the sea, and paucity of embankments able to face sea level rise, make it reasonable to assume that several areas located at present about $1 \mathrm{~m}$ a.s.l. will be partially flooded, unless drainage systems will adequately be developed (Fig. 8).

In the Cagliari coastal plain (Figs. 8 and 9), high rates of isostasy (GIA) (about $0.7 \mathrm{~mm} / \mathrm{yr}$, see Table 2) and local sediment compaction are the major driver of relative sea level rise, making the low lying western coastal plains at risk of marine flooding. As for Oristano, lack of natural banks and the presence of coastal human settle ments and infrastructures are important features that reduce the resilience of the coast, making it increasingly prone to marine flooding.

Apart from the obvious risk of submergence in low lying coastal areas, the increase in water depth that unavoidably will affect the lagoons due to RSLR could also influence the morphological equi librium of the wetlands. According to Fagherazzi et al. (2006) and Defina et al. (2007), the significant decline of tidal flats and salt marshes experienced during the last decades in the lagoons of Venice (Sarretta et al., 2010) and in the Marano and Grado lagoons (Fontolan et al., 2012) has been due to the increasing influence of the bottom shear stress due to wind waves, fully developed over open water lagoons, when the intertidal areas were submerged up to become subtidal.

The morphological response is a general tendency of the lagoon floor to flatten, either by erosion of the tidal flats, or through siltation of the channels, which in some cases have been filled completely. Flattening of the submerged landforms leads to a morphological simplification, resulting in lagoons that lose their typical shallow estuarine characteristics and change into marine embayments (Cooper, 1994). Moreover, even in presence of an amount of sediment sufficient to compensate for the morphological accommodation due to RSLR, data from the northern Grado Marano Lagoon show that the paradigm of the feedback between sediment supply to the lagoon and RSL may be compli cated by the intrinsic anisotropy of both variables within the lagoon (Fontolan et al., 2012). RSLR, thus, could cause either the "marinization" or the asymmetrical erosion of the northern Adriatic lagoons, depending on the amount of sediment supplied by the rivers.

Depending on the rate of RSLR, natural barrier island systems would cope with the submergence through a morphological shift (roll over) or overstepping. In place drowning of the barrier sys tems, linked to rapid submergence, occurred during the Holocene mostly in the northern Adriatic (Amorosi et al., 2008; Storms et al., 2008), but also took place in the Gulf of Oristano (De Falco et al.,
2015) and in the Gulf of Cagliari. Few data are available about the natural evolution of barrier systems during the last century, since most of the barrier islands facing the northern Adriatic lagoons are now urbanized and fixed. The present tendency of natural coastal barriers to roll over is observed only along the Friuli coastline, where possible evolution foresees the progressive filling of back barrier environments by washover processes, and the landward migration of the barriers against the anthropized ancient barrier system. This evolution will give rise to wider new beaches. Even applying the most conservative assumptions (i.e., the IPCC AR5 8.5 scenario, with maximum relative sea levels for 2100 ranging between 52 and $98 \mathrm{~cm}$ ), sea level rise in the gulfs of Oristano and Cagliari, in the absence of anthropogenic actions of protection, will likely be associated with the dismantling of beach ridges and barrier islands by washover, up to the progressive opening of the lagoons (marinization), and the subsequent adaptation of a bay (Fig. 9).

Our maps clarify the impact of sea level rise in consequence of climate change and vertical land movements, and should be considered for a conscious land planning and for adaptation strategies.

\section{Conclusions}

A significant sea level rise acceleration began in the 19th century and yielded a 20th century rise that is extremely likely (probability $\mathrm{P} \geq 0.95$ ) faster than during any of the previous 27 centuries (Kopp et al., 2016). Global sea level rise projections for 2100 range between 530 and $970 \mathrm{~mm}$ (IPCC, 2013, RCP 8.5 (www. ipcc.ch)), and up to about 500-1400 mm according to Rahmstorf (2007). These values of sea level rise will threaten many coastal cities, low lying islands and coastal plains on a global scale, even in absence of land subsidence. Even if the emissions of greenhouse gas will decrease, a sea level rise between 28 and $61 \mathrm{~cm}$ is still expected for the same period. In this optimistic scenario, more than half a meter of sea level rise will have an important impact along the coasts, causing diffuse erosion of the shorelines. More uncertain is the response of coastal systems to climate change in terms of sediment production and delivery. Rainfall can influence the sedimentary budget of the catchment basin, enhancing or weakening coastal progradation. Although the dynamics of these rapid morphodynamic changes triggered by climate change are unknown, it is reasonable to speculate that the combination of sea level rise and the decrease of sediment supply will determine a serious impact on many coastal areas. This impact will likely include the inland migration of the focus of coastal erosion, increasing significantly the risk of flooding, especially in case of extreme events.

For the investigated Italian region (North Adriatic, the Gulf of Taranto and Sardinia), assuming 530-970 mm (IPCC, 2013 RCP 8.5 (www.ipcc.ch)) and $1400 \mathrm{~mm}$ (Rahmstorf, 2007) of eustatic sea level rise, projections by 2100 (sum of eustatic, GIA and tectonic vertical movement) are 516-1010 $\mathrm{mm}$ for the IPCC scenarios and up to about $1430 \mathrm{~cm}$ for the Rahmstorf scenario of maximum sea 


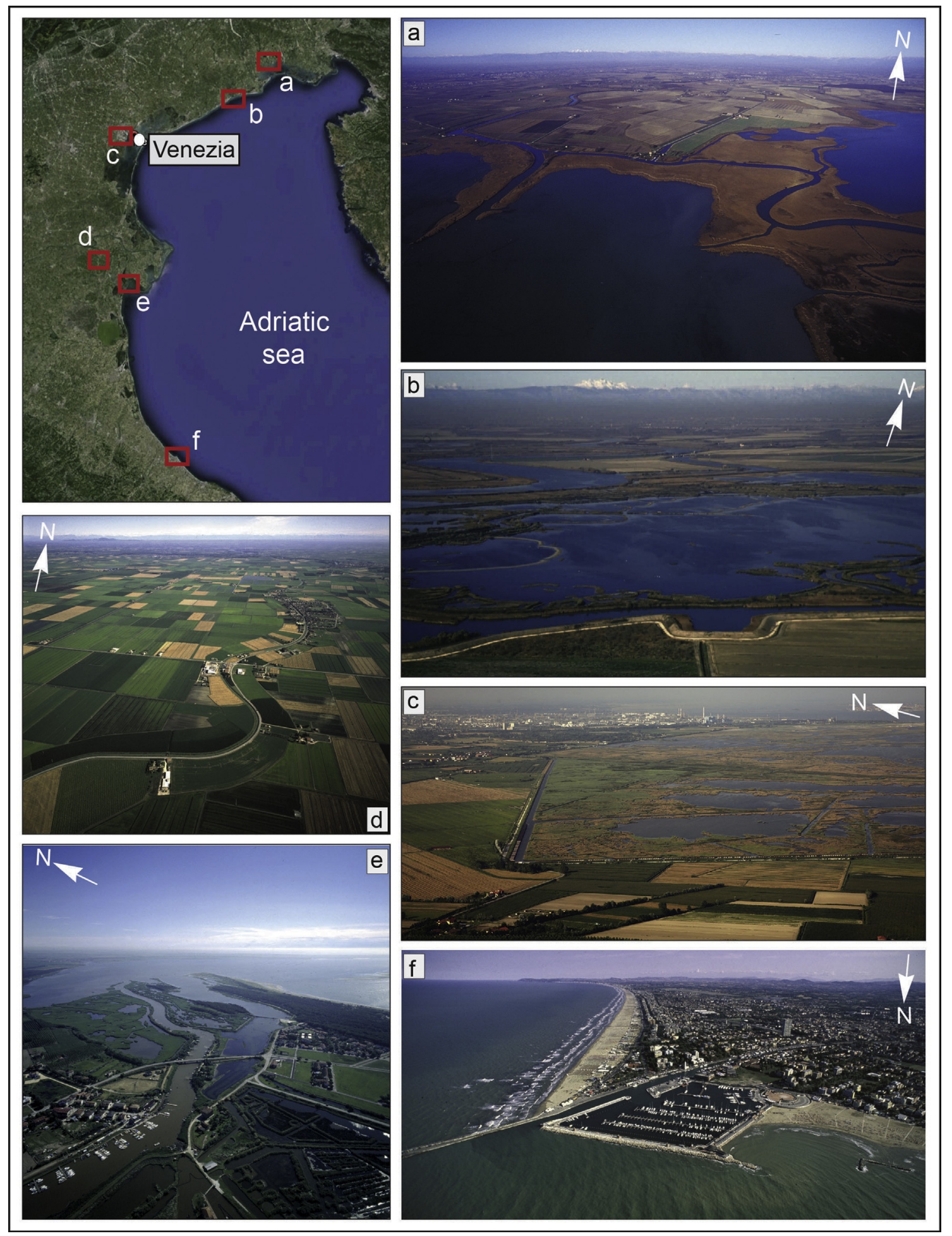

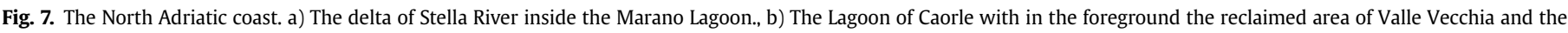

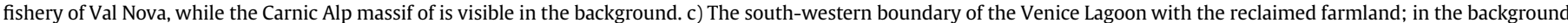

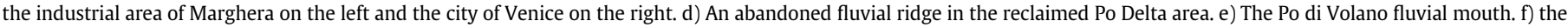
Rimini harbour. d, e, and f are courtesy of Regione Emilia-Romagna Geological, Seismic and Soil Survey.

level rise, once vertical land movements and DTM age are consid ered in the projections. This implies that the investigated coastal zones may become highly susceptible to marine inundation. This study documents that even for relatively lower sea level rise pro jections (IPCC), the vertical land movements caused by tectonic and isostatic components will produce an important additional contribution to relative sea level, with values up to a few $\mathrm{mm} / \mathrm{yr}$. While for the maximum rise of Rahmstorf (2007) climate change is the dominating signal, the current trend of sea level rise estimated at tide gauge stations and the rates of vertical land motion along the 


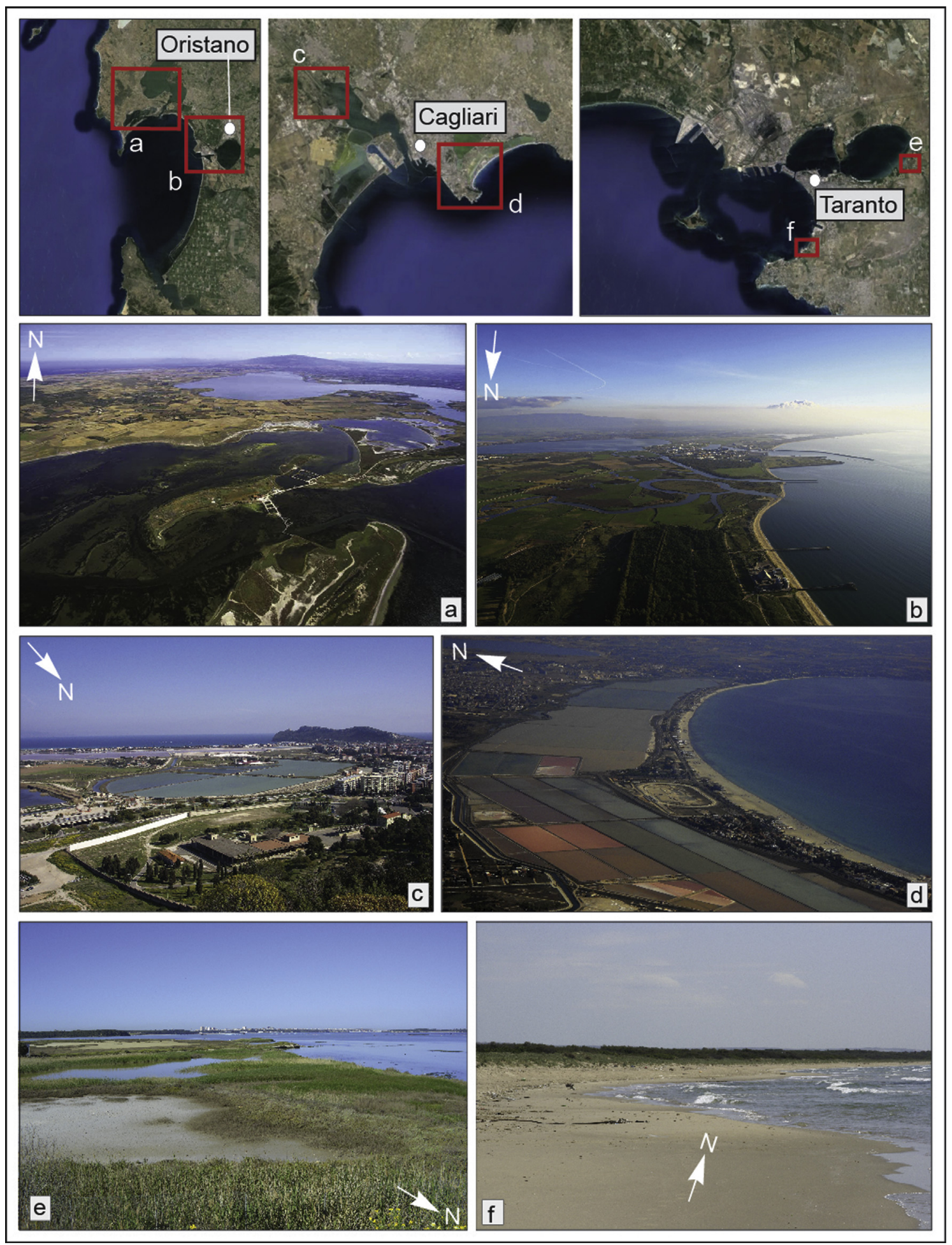

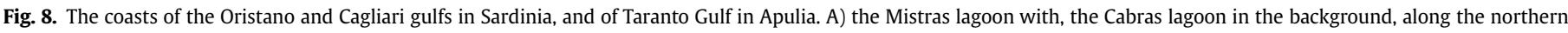

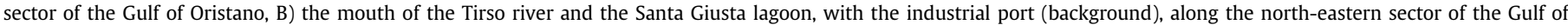

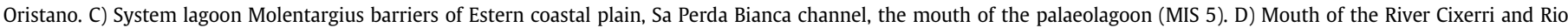

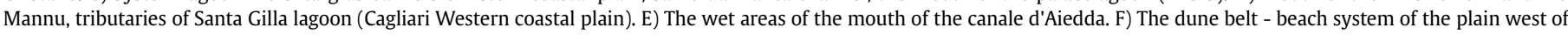
Taranto.

coasts inferred from GPS data suggest that sea level projections for 2100 based on the rates of subsidence inferred from long term (MIS 5 ) geological data may lead to underestimate the flooding scenarios. As a result, new CGPS stations co located with tide gauge stations along the coastal zones of Italy are required to monitor the relative sea level rates, also in combination with spatial data from radar altimeters and InSAR satellites. Anyway, these instrumental data confirm broadly long term vertical tectonic and isostatic movements.

Improved maps of multi temporal scenarios of marine flooding 

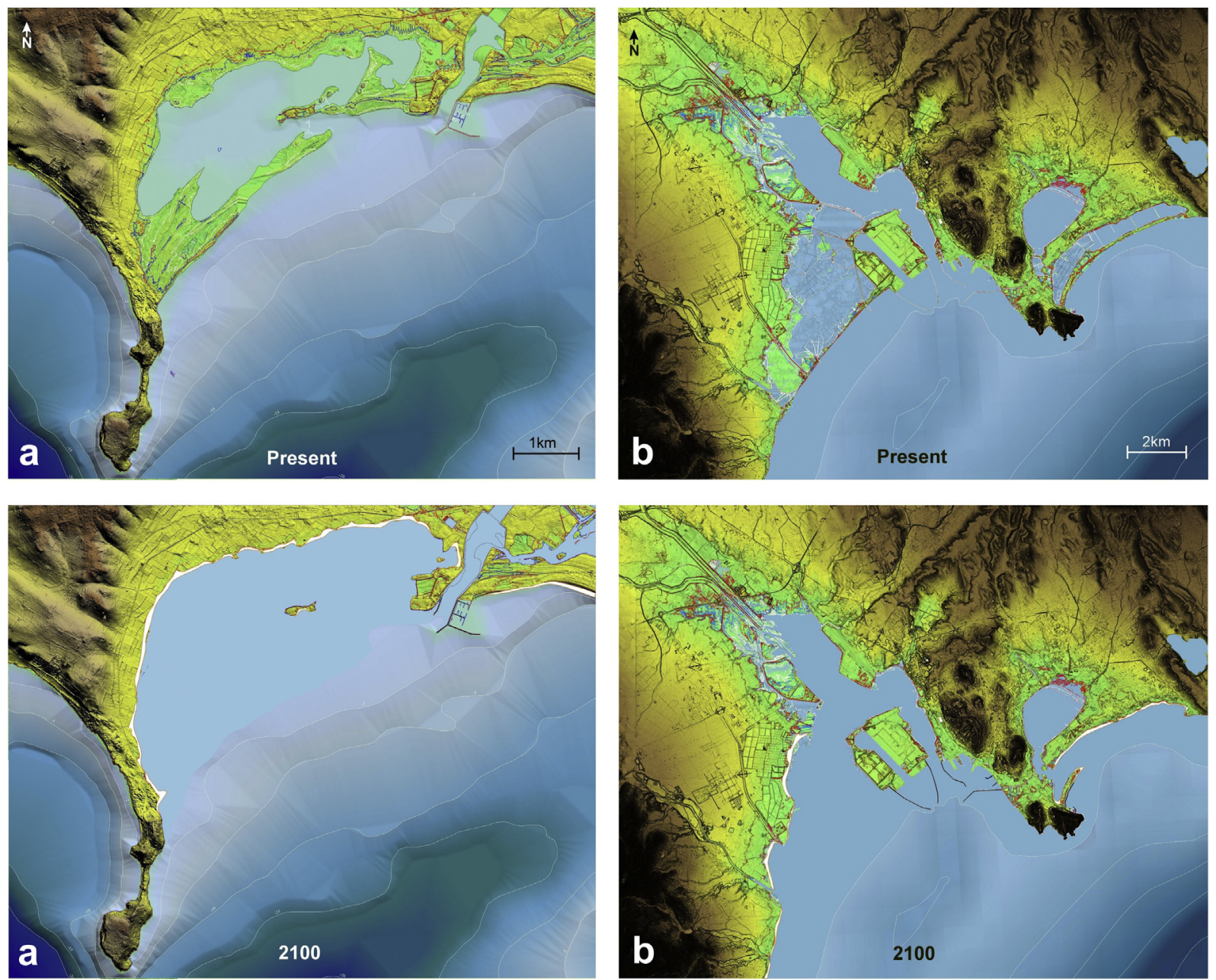

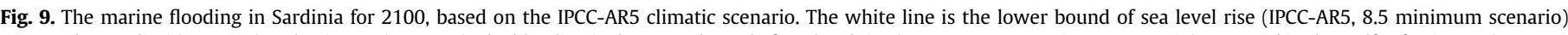

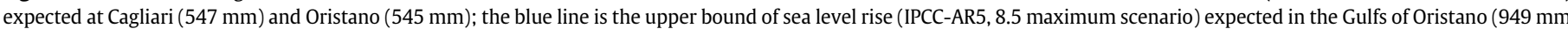

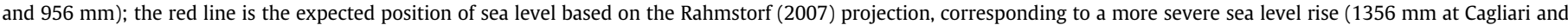

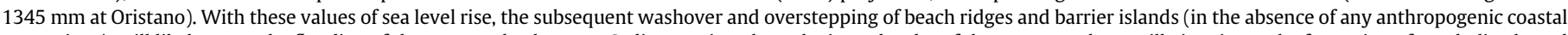

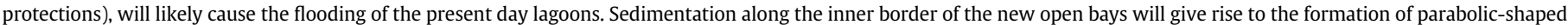
and pocket beaches. (For interpretation of the references to colour in this figure legend, the reader is referred to the web version of this article.)

based on these instrumental data will detail the expected marine flooding scenarios for 2100 and beyond, for those coastal zones prone to marine inundation. Finally, the method presented in this study for the Italian coast, that includes tectonic vertical move ments, isostasy and eustatic projections to estimates the extent of marine flooded areas, can be applied worldwide in other coastal areas expected to be affected by marine ingression due to global climate change.

\section{Acknowledgments}

We thanks two anonymous reviewers the give us the possibility to improve the manuscript. This study has been funded by the Italian National Research Council (CNR) in the frame of RITMARE Project and the Italian Ministry of Education, University and Research within the National Research local coordinator F. Antonioli. Program 2011-2013 PRIN (Response of morphoclimatic system dynamics to global changes and related geomorphologic hazard; $\mathrm{Na}$ tional coordinator: C Baroni; local Research Unit coordinators: M.Anzidei, G. Mastronuzzi) under the umbrella of the IGCP Project n. 639 by UNESCO e IUGS. LIDAR data were provided by Ministero dell'Ambiente e della Tutela del Territorio e del Mare Geoportale
Nazionale with license Creative Commons 3.0 Italy (CC BY SA 3.0IT). Bathymetric data were provided by GEBCO, ISPRA, IAMC CNR and EMODNET project. We thank Luisa Perini, Paolo Severi, and Paolo Luciani (Geological, Seismic and Soil Survey of Regione Emilia Romagna) who provided the DTM of the Emilia Romagna Region.

\section{Appendix A. Supplementary data}

Supplementary data related to this article can be found at http:// dx.doi.org/10.1016/j.quascirev.2016.12.021.

\section{References}

Achilli, V., Baldi, P., Baratin, L., Bonini, C., Ercolani, E., Gandolfi, S., Anzidei, M. Riguzzi, F., 1998. Digital photogrammetric survey on the island of Vulcano. Acta Vulcanol. 10, 16 .

Altamimi, Z., Collilieux, X., Métivier, L., 2011. ITRF2008: an improved solution of the international terrestrial reference frame. J. Geod. 85, 457473.

Amorosi, A., Fontana, A., Antonioli, F., Primon, S., Bondesan, A., 2008. Post-LGM sedimentation and Holocene shoreline evolution in the NW Adriatic coastal area. Geoacta 7, 4167.

Amorosi, A., Antonioli, F., Bertini, A., Marabini, S., Mastronuzzi, G., Montagna, P., Negri, A., Piva, A., Rossi, V., Scarponi, D., Taviani, M., Vai, G.B., 2014. The middle- 
late quaternary fronte section (Taranto, Italy): an exceptionally preserved ma-rine record of the last interglacial. Glob. Planet. Change 119, 2338.

Antonioli, F., Leoni, G., Gambarelli, G., Caiaffa, E., Goria, A., 2002. Fondi Plain (Latium, Italy), Sea Level Rise and Flooding Risk: Calculation of the Economic Amount of the Land Loss at 2100. Workshop ENEA Fondazione ENI Enrico Mattei. Technical Report ENEA 04.07.2002.

Antonioli, F., Anzidei, M.K., Auriemma, R., Gaddi, D., Furlani, S., Orrù, P., Solinas, E., Gaspari, A., Karinja, S., Kovacic, V., Surace, L., 2007. Sea level change during Holocene from Sardinia and northeastern Adriatic from archaeological and geomorphological data. Quat. Sci. Rev. 26, 24632486.

Antonioli, F., Ferranti, L., Fontana, A., Amorosi, A., Bondesan, A., Braitenberg, C., Dutton, A., Fontolan, G., Furlani, S., Lambeck, K., Mastronuzzi, G., Monaco, C. Spada, G., Stocchi, P., 2009. Holocene relative sea-level changes and vertical movements along the Italian coastline. Quat. Int. 206, 102133.

Anzidei, M., Antonioli, F., Lambeck, K., Benini, A., Soussi, M., 2011. New insights on the relative sea level change during Holocene along the coasts of Tunisia and western Libya from archaeological and geomorphological markers. Quat. Int. 232, 512

Anzidei, M., Lambeck, K., Antonioli, F., Furlani, S., Mastronuzzi, G., Serpelloni, E. Vannucci, G., 2014. Coastal Structure, Sea-level Changes and Vertical Motion of the Land in the Mediterranean. Geological Society, London, p. 388. http:// dx.doi.org/10.1144/SP388.20. Special Publications.

Anzidei, M., Bosman, A., Carluccio, R., Casalbore, D., D'Ajello Caracciolo, F., Esposito, A., Nicolosi, I., Pietrantonio, G., Vecchio, A., Carmisciano, C., Chiappini, M., Chiocci, F.L., Muccini, F., Sepe, V., 2016. Flooding scenarios in coastal volcanic areas due to land subsidence and sea level rise: a case study for Lipari Island (Italy). Terra Nova. http://dx.doi.org/10.1111/ter.12246.

Aucelli, P.C., Di Paola, G., Incontri, P., Rizzo, A., Vilardo, G., Benassai, G., Buonocore, B. Pappone, G., 2016. Coastal inundation risk assessment due to subsidence and sea level rise in a Mediterranean alluvial plain (Volturno coastal plain southern Italy). Estuar. Coast. Shelf Sci. http://dx.doi.org/10.1016/ j.ecss.2016.06.017.

Baiocchi, V., Anzidei, M., Esposito, A., Fabiani, U., Pietrantonio, G., Riguzzi, F., 2007. Integér bathymétrie et lidar. Geomatique 55, 2007.

Baltsavias, E.P., Favey, E., Bauder, A., Bosch, H., Pateraki, M., 2001. Digital surface modelling by airborne laser scanning and digital photogrammetry for glacier monitoring. Photogramm. Rec. 17 (98), 243273.

Benetazzo, A., Fedele, F., Carniel, S., Ricchi, A., Bucchignani, E., Sclavo, M., 2012 Wave climate of the Adriatic Sea: a future scenario simulation. Nat. Hazards Earth Syst. Sci. 12, 20652076.

Bondesan, M., Castiglioni, G.B., Elmi, C., Gabbinelli, G., Marocco, R., Pirazzoli, P.A., Tomasin, A., 1995. Coastal areas at risk from storm surges and sea level rise in Northeastern Italy. J. Coast. Res. 11, 1354 1379. Appendix: Elevation Map of the Po and Veneto Friuli Plain, scale 1:500,000.

Carbognin, L., Teatini, P., Tosi, L., 2004. Eustacy and land subsidence in the Venice

Lagoon at the beginning of the new millennium. J. Mar. Syst. 51, 345 353. Carillo A., Sannino, G., Artale, V., Ruti, P.M., Calmanti, S., Dell'Aquila, A., 2013. Steric sea level rise over the Mediterranean Sea: present climate and scenario simulations. Clim. Dyn. http://dx.doi.org/10.1007/s00382-012-1369-1.

Carreau, P.R., Gallego, F.J., 2006. EU25 Coastal Zone Population Estimates from the Disaggregated Population Density Data 2001. European Commission, DG Joint Research Centre.

Church, J.A., White, N.J., Aarup, T., Wilson, W.S., Woodworth, P., Domingues, C.M., Hunter, J.R., Lambeck, K., 2008. Understanding global sea levels: past, present

and future. Sustain. Sci. 3, 922.

Church, J.A., Woodworth, P.L., Aarup, T., Wilson, W.S., 2010. Understanding Sea Level Rise and Variability. Wiley-Blackwell Publishing, London, UK

Church, J.A., White, N.J., 2011. Sea-level rise from the late 19th to the early 21st century. Surv. Geophys. 4/5, 585 602. http://dx.doi.org/10.1007/

s10712-011-9119-1.

Church, J.A., Clark, P.U., Cazenave, A., Gregory, J.M., Jevrejeva, S., Levermann, A. Merrifield, M.A., Milne, G.A., Nerem, R.S., Nunn, P.D., Payne, A.J., Pfeffer, W.T. Stammer, D., Unnikrishnan, A.S., 2013. Sea level change. In: Climate Change 2013: the Physical Science Basis. Contribution of Working Group I to the Fifth Assessment Report of the Intergovernmental Panel on Climate Change. Cambridge University Press, Cambridge, United Kingdom and New York, NY, USA

Cooper, A., 1994. Sedimentary processes in the river- dominated estuary, SouthAfrica. Geomorphology 9, 271300.

D'Alessandro, L., Davoli, L., Lupia Palmieri, E., Raffi, R., 2002. Natural and anthropogenic factors of the recent evolution of beaches in Calabria (Italy). In: Allison, R.J. (Ed.), Applied Geomorphology: Theory and Practice. John Wiley \& Sons, Ltd., Chichester, pp. 397427.

De Falco, G., Antonioli, F., Fontolan, G., Lo Presti, V., Simeone, S., Tonielli, R., 2015. Early cementation and accommodation space dictate the evolution of an overstepping barrier system during the Holocene. Mar. Geol. 369, 52 66. Defina, A., Carniello, L., Fagherazzi, S., D'Alpaos, L., 2007. Self organization of shallow basins in tidal flats and salt marshes. J. Geophys. Res. 112, F03001. http:// dx.doi.org/10.1029/2006JF000550.

Di Bucci, D., Caputo, R., Mastronuzzi, G., Fracassi, U., Selleri, G., Sansò, P., 2011. First evidence of Late Quaternary tectonics from joint analysis in the southern Adriatic foreland (Italy). J. Geodyn. 51, 141155.

Fagherazzi, S., Carniello, L., D'Alpaos, L., Defina, A., 2006. Critical bifurcation of shallow microtidal landforms in tidal flats and salt marshes. PNAS 103 (22), 8337 8341. http://dx.doi.org/10.1073/pnas.0508379103.

Fabris, M., Baldi, P., Anzidei, M., Pesci, A., Bortoluzzi, G., Aliani, S., 2010. High resolution topographic model of Panarea Island by fusion of photogrammetric Lidar and bathymetric Digital Terrain Models. Photogramm. Rec. 25 (132), 382401.

Farr, T.G., Rosen, P.A., Caro, E., Crippen, R., Duren, R., Hensley, S., Kobrick, M., Paller, M., Rodriguez, E., Roth, L., Seal, D., Shaffer, S., Shimada, J., Umland, J., 2007. The Shuttle radar topography mission. Rev. Geophys. 45, RG2004. http:// dx.doi.org/10.1029/2005RG000183.

Ferranti, L., Antonioli, F., Amorosi, A., Dai Pra, G., Mastronuzzi, G., Mauz, B. Monaco, C., Orrù, P., Pappalardo, M., Radtke, U., Renda, P., Romano, P., Sanso, P. Verrubbi, V., 2006. Elevation of the last interglacial highstand in Italy: a benchmark of coastal tectonics. Quat. Int. $145146,3054$.

Ferranti, L., Antonioli, F., Anzidei, M., Monaco, C., Stocchi, P., 2010. The timescale and spatial extent of vertical tectonic motions in Italy: insights from relative sea-level changes studies. J. Virtual Explor. http:// dx.doi.org/10.3809/jvirtex.2009.00255.

Fontolan, G., Pillon, S., Bezzi, A., Villalta, R., Lipizer, M., Triches, A., Daietti, A., 2012 Human impact and the historical transformation of saltmarshes in the Marano and Grado lagoon, northern Adriatic sea. Estuar. Coast. Shelf Sci. 113, 4156.

Galassi, G., Spada, G., 2014. Sea-level rise in the Mediterranean Sea by 2050: roles terrestrial ice melt, steric effects andbflacial isostatic adjustment. Glob. Planet. Change 123, 5566

Herring, T., King, R.W., McClusky, S., 2010. GAMIT Reference Manual, Release 10.4. Massachussetts Institute of Technology, Cambridge, MA

Hengl, T., Reuter, H.I., 2009. Geomorphometry, Concepts, Software, Applications. Developments in Soil Science, 33. Elsevier, p. 765.

Jevrejeva, S., Moore, J.C., Grinsted, A., Woodworth, P.L., 2008. Recent global sea level acceleration started over 200 years ago? Geophys. Res. Lett. 35 http://dx.doi.org/10.1029/2008gl033611.

Horton, B.P., Rahmstorf, S., Engelhart, S.E., Kemp, A.C., 2014. Expert assessment of sea-level rise by AD 2100 and AD 2300. Quat Sci Rev. 84, 16.

Jevrejeva, S., Moore, J.C., Grinsted, A., Matthews, A.P., Spada, G., 2014. Trends and acceleration in global and regional sea levels since 1807. Glob. Planet. Change $113,1122$.

Jorda, G., Gomis, D., 2013. On the interpretation of the steric and mass components of sea level variability: the case of the Mediterranean basin. J. Geophys. Res. Oceans 118, 953963.

Karim, F., Mimura, N., 2011. Impacts of climate change and sea-level rise on cyclonic storm surge floods in Bangladesh Mohammed. Glob. Environ. Change 18, 490 500 .

Kemp, A.C., Horton, B., Donnelly, J.P., Mann, M.E., Vermeer, M., Rahmstorf, S.,

201 Climate related sea level variations over the past two millennia. PNAS 108 1101711022

Kopp, R.E., Kemp, A.C., Bittermann, K., Horton, B.P., Donnelly, J.P., Gehrels, W.R. Hay, C.C., Mitrovica, J.X., Morrow, E.D., Rahmstorf, S., 2016. Temperature-driven global sea-level variability in the Common Era. PNAS E1434 E1441. http:// dx.doi.org/10.1073/pnas.1517056113.

Lambeck, K., Antonioli, F., Anzidei, M., Ferranti, L., Leoni, G., Scicchitano, G., Silenzi, S., 2011. Sea level change along Italian coast during Holocene and projection for the future. Quat. Int. 232 (1 2), 250 257. http://dx.doi.org 10.1016/j.quaint.2010.04.026.

Lambeck, K., Purcell, A., 2005. Sea-level change in the Mediterranean since the LGM: model predictions for tectonically stable areas. Quat. Sci. Rev. 24 19691988

Lambeck, K., Antonioli, F., Purcell, A., Silenzi, S., 2004a. Sea-level change along the Italian coast for the past 10,000 yrs. Quat. Sci. Rev. 23, 15671598.

Lambeck, K., Anzidei, M., Antonioli, F., Benini, A., Esposito, A., 2004b. Sea level in Roman times in the Central Mediterranean and implications for recent change.

Earth Planet. Sci. Lett. 224, 563575.

Lionello, P., Cogo, S., Galati, M.B., Sanna, A., 2008. The Mediterranean surface wave climate inferred from future scenario simulations. Glob. Planet. Change 63 (2 3), 152162

Lionello, P., Galati, M.B., Elvini, E., 2012. Extreme storm surge and wind wave climate scenario simulations at the Venetian littoral. Phys. Chem. Earth Parts A/B C $4041,8692$.

Lisco, S., Corselli, C., De Giosa, F., Mastronuzzi, G., Moretti, M., Siniscalchi, A Marchese, F., Bracchi, V., Tessarolo, C., Tursi, A., 2015. Geological maps of a marine area polluted by industrial discharges (Mar Piccolo, Taranto, Southern Italy): the physical basis for remediation. J. Maps. http:// dx.doi.org/10.1080/ 17445647.2014.999136.

Mariani, P., Braitenberg, C., Antonioli, F., 2009. Sardinia coastal uplift and Volcanism. Pure Appl. Geophys. 166, 13691402.

Mastronuzzi, G., Quinif, Y., Sanso, P., Selleri, G., 2007. Middle-Late Pleistocene polycyclic evolution of a geologically stable coastal area (southern Apulia, Italy).

Geomorphology 86, 393408

Mastronuzzi, G., Sanso, P., 2002. Pleistocene sea level changes, sapping processes and development of valleys network in Apulia region (southern Italy). Geo-morphology 46, 1934.

Mastronuzzi, G., Sansò, P. (Eds.), 2003. Quaternary Coastal Morphology and Sea Level Changes. Puglia 2003, Final Conference Project IGCP 437 UNESCO IUGS, Otranto/Taranto - Puglia (Italy) 2228 September 2003, 5. GIS Coast Gruppo Informale di Studi Costieri, Research Publication, Brizio srl - Taranto, p. 184.

Meyssignac, B., Cazenave, A., 2012. Sea level: a review of present-day and recent-

past changes and variability. J. Geodyn. 58, 96109

Mengel, M., Levermann, A., Frieler, K., Robinson, L., Marzeion, B., Winkelmann, 
2016. Future sea level rise constrained by observations and long-term commitment. PNAS 113, 10.

Mitchum, G.T., Nerem, R.S., Merrifield, M.A., Gehrels, W.R., 2010. Modern sea level changes estimates. In: Church, J.A., Woodworth, P.L., Aarup, T., Wilson, W.S.(Eds.), Understanding Sea Level Rise and Variability. Wiley-Blackwell Publish-ing, London, UK.

Negri, A., Amorosi, A., Antonioli, F., Bertini, A., Florindo, F., Lurcock, P.C., Marabini, S., Mastronuzzi, G., Regattieri, E., Rossi, V., Scarponi, D., Taviani, M., Zanchetta, G., Vai, G.B., 2014. A potential global boundary stratotype section and point (GSSP) for the Tarentian stage, Upper Pleistocene, from Taranto area Italy: results and future perspectives. Quat. Int. 18, 109119.

Orrù, P.E., Antonioli, F., Lambeck, K., Verrubbi, V., 2004. Holocene Sea-level Change in the Cagliari Coastal Plain. Quaternaria nova, VIII, South Sardinia, Italy,

pp. 193210.

Orrù, P.E., Antonioli, F., Hearty, P.J., Radtke, U., 2011. Chronostratigraphic confirmation of MIS 5 age of a baymouth bar at Is Arenas (Cagliari, Italy). Quat. Int. 232 (1 2), 169178

Orrù, P.E., Mastronuzzi, G., Deiana, G., Pignatelli, C., Piscitelli, A., Solinas, E., Spanu, P.G., Zucca, R., 2014. Sea level changes and geoarchaeology between malfatano bay and piscinnì bay (SW Sardinia) in the last 4 ky. Quat. Int. 336, 180189.

Perini, L., Calabrese, L., Salerno, G., Ciavola, P., Armaroli, C., 2016. Evaluation of coastal vulnerability to flooding: comparison of two different methodologies adopted by the Emilia-Romagna region (Italy). Nat. Hazards Earth Syst. Sci. 16, 181194.

Pesci, A., Fabris, M., Conforti, D., Loddo, F., Baldi, P., Anzidei, M., 2007. Integration of ground-based laser scanner and aerial digital photogrammetry for topographic modelling of Vesuvio volcano. J. Volcanol. Geotherm. Res. 162, 123 138. Rahmstorf, S., 2007. A semi-empirical approach to projecting future sea-level rise. Science 315,368370

Rahmstorf, S., Perrette, M., Vermeer, M., 2011. Testing the robustness of semiempirical sea level projections. Clim. Dyn. 39, 861875.

Rosenzweig, C., Solecki, W.D., Blake, R., Bowman, M., Faris, C., Gornitz, V., Horton, R., Jacob, K., LeBlanc, A., Leichenko, R., Linkin, M., Major, D., O'Grady, M., Patrick, L., Sussman, E., Yohe, G., Zimmerman, R., 2011. Developing coastal adaptation to climate change in the New York City infrastructure-shed: rocess, approach, tools, and strategies. Clim. Change 106, 93127.

Sarretta, A., Pillon, S., Molinaroli, E., Guerzoni, S., Fontolan, G., 2010. Sediment budget in the lagoon of Venice. Cont. Shelf Res. 30, 934949.

Schaeffer, M., Hare, W., Rahmstorf, S., Vermeer, M., 2012. Long-term sea-level rise implied by $1.5{ }^{\circ} \mathrm{C}$ and $2{ }^{\circ} \mathrm{C}$ warming levels. Nat. Clim. Change 2, 867870 .

Serpelloni, S., Faccenna, C., Spada, G., Dong, D., Williams, S.D.P., 2013. Vertical GPS ground motion rates in the Euro-Mediterranean region: new evidence of velocity gradients at different spatial scales along the Nubia Eurasia plate boundary. J. Geophys. Res. 118, 122.

Snoussi, M., Ouchani, T., Niazi, S., 2008. Vulnerability assessment of the impact of sea-level rise and flooding on the Moroccan coast: the case of the Mediterra-

nean eastern zone. Estuar. Coast. Shelf Sci. 77, 206213.

Sterr, H., Klein, R.J.T., Reese, S., 2003. Climate Change and Coastal Zones: an

Oveview of the State-of the-art on Regional and Local Vulnerability Assessment. Published in: Climate Change and the Mediterranean: Socio-economics of impacts, vulnerability and adaptation, 2003. Available at: http://www.feem.it/ getpage.aspx?id 765\&sez Publications\&padre 73 .

Storms, J.E.A., Weltje, G.J., Terra, G.J., Cattaneo, A., Trincardi, F., 2008, Coastal dynamics under conditions of rapid sea-level rise: late Pleistocene to Early Holocene evolution of barrier lagoon systems on the northern Adriatic shelf (Italy). Quat. Sci. Rev. 27, 11071123.

Strauss, B., Ziemlinski, H.R., Weiss, J.L., Overpeck, J.T., 2012. Tidally adjusted estimates of topographic vulnerability to sea level rise and flooding for the contiguous United States. Environ. Res. Lett. 7, 112.

Syvitski, J.P.M., Kettner, A.J., Overeem, I., Hutton, E.W.H., Hannon,

M.TBrakenridge, G.R., Day, J., Vorosmarty, C., Saito, Y., Giosan, L., Nicholls, R.J., 2009 Sinking deltas due to human activities. Nat. Geosci. 2, 681686.

Tarquini, S., Isola, I., Favalli, M., Mazzarini, F., Bisson, M., Pareschi, M.T., Boschi, E., 2007. TINITALY/01: a new triangular irregular network of Italy. Ann.

Geophys. 50, 407425

Veermer, M., Rahmstorf, S., 2009. Global sea level linked to global temperature. PNAS 106 (51), 2152721532.

Weisse, R., Bellafiore, D., Menéndez, M., Mèndez, F., Nicholls, R.J., Umgiesser, G., Willems, P., 2014. Changing extreme sea levels along European coasts. Coast. Eng. 87, 414

Woppelmann, G., Marcos, M., 2012. Coastal sea level rise in southern Europe and the nonclimate contribution of vertical land motion. J. Geophys. Res. 117, C01007. http://dx.doi.org/10.1029/2011JC007469.

Zecca, A., Chiari, L., 2012. Lower bounds to future sea-level rise. Glob. Planet. Change 9899,15 